\title{
Cladosporol A Stimulates G1-Phase Arrest of the Cell Cycle by Up-Regulation of p21 waf1/cip1 Expression in Human Colon Carcinoma HT-29 Cells
}

\author{
Diana Zurlo, ${ }^{1}$ Cinzia Leone, ${ }^{1}$ Gemma Assante, ${ }^{2}$ Salvatore Salzano, ${ }^{3}$ Giovanni Renzone, ${ }^{4}$ Andrea Scaloni, ${ }^{4}$ \\ Caterina Foresta, ${ }^{1}$ Vittorio Colantuoni, ${ }^{1,5}$ and Angelo Lupo ${ }^{1,5 *}$ \\ ${ }^{1}$ Dipartimento di Scienze Biologiche ed Ambientali, Facoltà di Scienze, Università del Sannio, Benevento, Italy \\ ${ }^{2}$ Dipartimento di Patologia Vegetale Università degli Studi di Milano, Milano, Italy \\ ${ }^{3}$ CNR Istituto di Endocrinologia ed Oncologia Sperimentale "G. Salvatore", Università Federico II, Napoli, Italy \\ ${ }^{4}$ Laboratorio di Proteomica e Spettrometria di Massa, ISPAAM, Consiglio Nazionale delle Ricerche, Napoli, Italy \\ ${ }^{5}$ Dipartimento di Biochimica e Biotecnologie Mediche Università Federico II, Napoli, Italy
}

Cladosporols, purified and characterized as secondary metabolites from Cladosporium tenuissimum, display an antifungal activity. In this study, we tested the antiproliferative properties of cladosporol A, the main isoform of this metabolite family, against human cancer cell lines. By assessing cell viability, we found that cladosporol A inhibits the growth of various human colon cancers derived cell lines (HT-29, SW480, and CaCo-2) in a time- and concentrationdependent manner, specifically of HT-29 cells. The reduced cell proliferation was due to a G1-phase arrest, as assessed by fluorescence activated cell sorting analysis on synchronized HT-29 cells, and was associated with an early and robust over-expression of p21 waf1/cip1, the well-known cyclin-dependent kinases inhibitor. This suggests that the drug may play a role in the control of cancer cell proliferation. Consistently, cyclin D1, cyclin E, CDK2, and CDK4 proteins were reduced and histone $\mathrm{H} 1$-associated CDK2 kinase activity inhibited. In addition to p21waf1/cip1, exposure to $20 \mu \mathrm{M}$ cladosporol A caused a simultaneous increase of pERK and pJNK, suggesting that this drug activates a circuit that integrates cell cycle regulation and the signaling pathways both involved in the inhibition of cell proliferation. Finally, we showed that the increase of $\mathrm{p} 21^{\text {waf1/cip } 1}$ expression was generated by a Sp1-dependent $\mathrm{p} 53$-independent stimulation of its gene transcription as mutagenesis of the Sp1 binding sites located in the p21 proximal promoter abolished induction. To our knowledge, this is the first report showing that cladosporol A inhibits colon cancer cell proliferation by modulating p21waf1/cip1 expression. @ 2011 Wiley Periodicals, Inc.

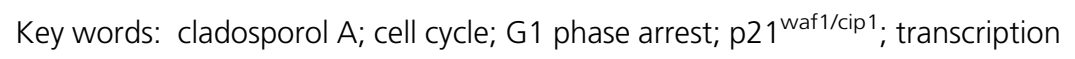

\section{INTRODUCTION}

Chemoprevention consists in the administration of natural and/or synthetic compounds to prevent the occurrence of degenerative diseases and, more recently, various cancer types. Vitamins, minerals, carotenoids, flavonoids, organsulfurs, isothiocyanates, indoles, monoterpenes, phenolic acids, and chlorophylls, are all included in the list of natural and already available compounds able to interfere with the various steps of the carcinogenetic process through different mechanisms and distinctive molecules [1-3]. Isolation and characterization of new natural molecules from plants, fungi, and microrganisms will increase the number of these therapeutic tools to inhibit cancer cells proliferation.

Cladosporols are secondary metabolites purified from Cladosporium tenuissimum, strain ITT21, cultured in sugar-rich media [4]. This fungus is a hyperparasite of rust fungi and its derived compounds possess antifungal activity [5]. The main metabolite was isolated as a white powder, representing more than $30 \%$ of the crude extract (Figure 1A). Its spectral analyses were consistent with a $\mathrm{C}_{20} \mathrm{H}_{16} \mathrm{O}_{6}$ molecular formula and a dimeric decaketide binaphthyl structure [6]. Cladosporols were initially characterized as plant regulators,

Abbreviations: CRC, colorectal cancer: CDK, cyclin-dependent kinase; CDKI, cyclin-dependent kinase inhibitor; ERK, extracellular signal-regulated protein kinase; JNK, c-Jun NH2-terminal kinase; PCNA, proliferating cell nuclear antigen; RB, retinoblastoma; DMEM, Dulbecco's Modified Eagle's Medium; FBS, fetal bovine serum; RT-PCR, reverse transcriptase-polymerase chain reaction; GAPDH, glyceraldehyde-3-phosphate dehydrogenase; MAPKs, mitogen-activated protein kinases; MS, mass spectrometry.

*Correspondence to: Dipartimento di Scienze Biologiche ed Ambientali, Facoltà di Scienze, Università del Sannio, via Port'Arsa 11, 82100 Benevento, Italy.

Received 10 January 2011; Revised 2 September 2011; Accepted 19 September 2011

DOI 10.1002/mc.20872

Published online in Wiley Online Library (wileyonlinelibrary.com). 


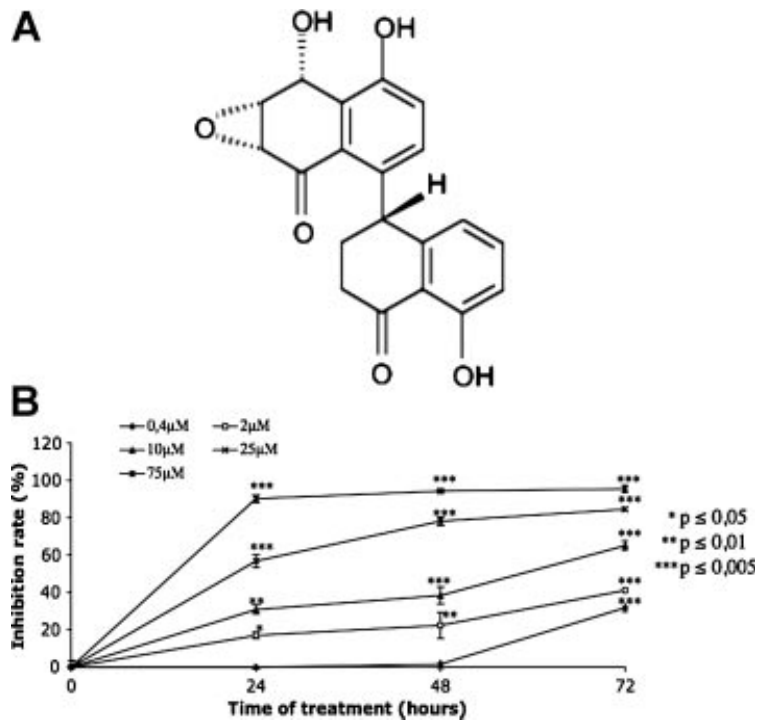

Figure 1. (A) Chemical structure of cladosporol A. (B) Dosedependent cytotoxicity of cladosporol A on HT-29 cells, as determined by the CellTiter Aqueous One Cell Proliferation Assay. Cells were seeded in 96-well plates in order to reach the density of $10^{6} \mathrm{cells} / \mathrm{cm}^{2}$ in standard conditions $(10 \%$ charcoal $/$ dextrantreated FBS containing $1 \%$ penicillin-streptomycin and $1 \%$ L-glutamine). After $24 \mathrm{~h}$, increasing concentrations of cladosporol $A$ (from 0.4 to $75 \mu \mathrm{M}$ ) were used to stimulate cells and the growth was evaluated up to $72 \mathrm{~h}$ through measurement of absorbance at $490 \mathrm{~nm}$. Results were expressed as the optical density ratio of the difference between the control and the treated cells to the contro cells. Each point was done in triplicate and the experiment was repeated two times.

then as inducers of hyphal malformations in Phytophothora capsici and, lastly, as inhibitors of $\beta-1,3-$ glucan synthetase, the enzyme responsible for the synthesis of the fungal cell wall components $[7,8]$. Cladosporols are able to inhibit almost completely spore germination in a great number of rust fungi, such as Uromyces appendiculatus, Melampsora pinitorqua, Cronartium flaccidum, and provoke the reduction of radial growth of non-rust fungi as in colonies of the phytopathogenic fungi like Alternaria alternata, Botrytis cinerea, Cercospora beticola, among the Oomycota, Phytophthora capsici, $P$. cinnamomi, $P$. erytroseptica and among human pathogenic strains of Candida sp. The antifungal activity of cladosporols likely resides in the intrinsic toxicity of the 2-tetralone chromophore and in highly reactive functionalities, such as the epoxy-alcohol moiety, very similar to $(+)$-isoepoxidon, also reported as a $\beta$-1, 3-glucan biosynthesis inhibitor, or other similar compounds [9-11]. These bioactive molecules strongly influence the pathogenicity of $C$. tenuissimum and play a major role in its hyperparasitism.

Colorectal cancer (CRC) is one of the most widespread tumors in Western countries. The most recent statistics confirm that only in the USA about 146,970 new cases of CRCs will be diagnosed in the next year and 49,920 patients will die of this disease [12]. In addition to genetic alterations in tumor suppressor genes, such as P53 and adenomatous polyposis coli $(A P C)$, loss of cell cycle control, increased cell survival signaling and inhibition of apoptosis are the most common events observed in CRC promotion and/or progression [13-15].

For these reasons, new molecules affecting the cell cycle might be helpful tools to prevent the earliest events in carcinogenesis $[16,17]$. Cell cycle progression is modulated by cyclins and cyclindependent kinases (CDKs) interactions [18]. These protein complexes are sequentially activated during the cell cycle allowing the transition through the G1, S, and G2/M phases [19]. Under different conditions, the cyclin-CDK complexes are inhibited by the binding of CDK inhibitors (CDKIs), two main groups of which have been identified and characterized so far, the CIP/KIP and INK4 families $[20,21]$. p21 $1^{\text {waf } 1 / \text { cip } 1}$ is one of the most important members of the CIP/KIP family, is recognized as a fundamental player in the control of cell proliferation [22,23] and identified as the target of the p53-dependent growth-arrest after DNA-damage induction in various cell types $[24,25]$. Indeed, p2 $1^{\text {waf1/cip1 }}$ expression is modulated through p53-dependent and -independent mechanisms $[26,27]$. The majority of human cancers bear mutated forms of p53 and, therefore, it is interesting to investigate p53-independent but p21-mediated mechanisms of cell cycle regulation. Novel findings on this topic might suggest new potential intervention in managing human cancers.

Epidemiologic studies demonstrated a tight correlation between CRC diffusion and red meat, fatty acids, and alcohol intake [28]. Moreover, a dramatic difference in CRC incidence has been observed among populations of different ethnic groups that may be ascribable to the different dietary regimens followed in the different countries [29]. Thus, CRC frequency in Europe and USA (where the consumption of fat and red meat in the diet is very high) is higher than that observed in Asia (where people are used to eating large amounts of vegetables). Consumption of high amounts of fruit and vegetables may result in a reduction of CRC occurrence and, therefore, a chemopreventive approach could be a productive strategy to control the disease diffusion [30-32].

Along this reasoning, Chen et al. [33] have recently demonstrated that the growth of the human gastric carcinoma derived cells (MGC-803) is inhibited by cladosporol isolated from the paclitaxel-producing strain Alternaria alternata var: monosporus. Here, we tested the antiproliferative properties of cladosporol A on three CRC derived cell lines (HT-29, SW480, and CaCo-2) to elucidate the underlying molecular mechanisms. In particular, we show that exposure of HT-29 cells to the drug causes a p21-dependent, p53-independent 
cell cycle arrest at the G1/S phase. This effect is accompanied by a robust $\mathrm{p} 21^{\text {waf1/cip1 }}$ overexpression, a significant CDK2, CDK4, cyclin D1, and cyclin E protein down-regulation and a CDK2 kinase activity inhibition. Moreover, we provide the first evidence that extracellular signal-regulated protein kinase (ERK) [and c-Jun NH2-terminal kinase (JNK) also] might function as mediator of the cladosporol A-induced redox response and inhibition of HT-29 cell growth. Finally, our findings demonstrate that cladosporol Amediated impairment of CRC cell survival is due to an Sp1-modulated increase of $\mathrm{p} 21^{\text {waf1/cip1 }}$ gene transcription.

\section{MATERIALS AND METHODS}

\section{Cells, Antibodies, and Reagents}

HT-29, SW480, CaCo-2, and HCT116 (from human colon cancers) cells were obtained from the American Type Culture Collection (Rockville, MD). These cell lines bear different genetic abnormalities typical of human CRC, because they have truncated or mutant APC gene. Moreover, SW480 cells express both P53 (Arg273 > His and Pro309 > Ser) and RAS (Val12 > Glu) mutated forms. HT-29 cells bear a mutated p53 (Arg $273>$ His), but a wildtype ras allele. HCT116 cells carry a mutated form of RAS and a wild-type P53. HCT116 p53-/- were a kind gift from Dr. Bevilacqua (University of Naples "Federico II"). Finally, CaCo-2 cells express wild-type $R A S$, but carry a mutated p53 allele form [34].

Antibodies against $\mathrm{p} 21^{\text {waf1/cip1 }}$, cyclin E, D1, A and B1, CDK2, CDK4, Cdc2p34, proliferating cell nuclear antigen (PCNA), pERK, pJNK, p53, retinoblastoma (RB), and $\beta$-actin were purchased from Santa Cruz Biotechnology (Santa Cruz, CA). Antimouse and anti-rabbit IgG peroxidase-linked secondary antibodies, A/G plus agarose beads, ECL and ECL Plus Western blotting detection kit were purchased from Amersham Life Science (Little Chalfont, England). Dulbecco's Modified Eagle's Medium (D-MEM), RPMI1640, D-luciferin sodium salt, trichloroacetic acid, propidium iodide (PI), thiazolinedione, apocynin, UO126 and PD98059 were from Sigma (St.Louis, MO). Fetal bovine serum (FBS), penicillin-streptomycin, L-glutamine, trypsin-EDTA, and OptiMEM I were obtained from Gibco (Carlsbad, CA). Charcoal/dextran-treated FBS was purchased from Hyclone (Logan, Utah). Fetal calf serum, Lipofectamine 2000, TRIZOL, SuperScript II reverse transcriptase were from Invitrogen (Carlsbad, CA). The CellTiter Aqueous One Cell Proliferation Assay was obtained from Promega (Madison, WI). SYBR Green and Ready Strip IPG strips were purchased from BioRad (Hercules, CA). AmpliTaq Gold was purchased from Applied Biosystems (Foster City, CA).

\section{Cell Culture and Cladosporol A Treatment}

Human colon adenocarcinoma cell lines HT-29, Caco-2, and SW480 were grown as a monolayer in D-MEM containing 10\% FBS, $1 \%$ penicillinstreptomycin, and 1\% L-glutamine. HCT116 were grown in RPMI1640 medium containing 10\% FBS, $1 \%$ penicillin-streptomycin and $1 \%$ L-glutamine. All the cells were cultured in $100 \mathrm{~mm}$ plates, at $70-80 \%$ confluence, in a $5 \% \mathrm{CO}_{2}$ humidified atmosphere, at $37^{\circ} \mathrm{C}$.

Cladosporol A treatments were carried out in presence of $10 \%$ charcoal/dextran-treated FBS containing $1 \%$ penicillin-streptomycin and $1 \%$ L-glutamine, whereas the cells were maintained at $40 \%$ confluence. Cladosporol A was dissolved in dimethylsulfoxide (DMSO) and mixed with fresh medium to achieve the final concentration. In all treatments, the DMSO final concentration in the medium was $<0.1 \%$. In separate experiments, cells were treated with increasing concentrations of cladosporol $\mathrm{A}$, for the indicated times. We also performed the same experiments by culturing the cells in D-MEM (or RPMI1640) containing $10 \% \mathrm{FBS}$ and the results obtained were identical.

\section{Cell Viability and Lipid Peroxidation Assays}

The growth rate of HT-29 cells was evaluated using the CellTiter Aqueous One Cell Proliferation Assay (Promega, Madison, WI), following the manufacturer's procedure. Cells were seeded in 96-well plates in order to reach the density of $10^{6}$ cells/ $\mathrm{cm}^{2}$ in standard conditions (10\% FBS). After $24 \mathrm{~h}$, increasing concentrations of cladosporol (from 0.4 to $75 \mu \mathrm{M}$ ) were added to stimulate cells and the growth was evaluated from 24 up to $72 \mathrm{~h}$. The inhibition rate was expressed as the optical density ratio of the difference between the control and the treated cells to the control. The concentration of cladosporol A required for $50 \%$ reduction in cell survival $\left(\mathrm{IC}_{50}\right)$ was calculated using standard curves. Each time point was done in triplicate and the experiment repeated at least two times. The absorbance at $490 \mathrm{~nm}$ was measured on a microplate reader (BenchMark, Bio-Rad, Hercules, CA).

To further evaluate cell growth after treatment with cladosporol A, cells were plated in 12-well plates at density of $10^{6}$ cells $/ \mathrm{cm}^{2}$. After treatment, the cells were washed with PBS, trypsinized and collected in culture medium. Cell counting was performed by means of a Bürker's hemocytometer. Three counts for each well were made and the mean value and the standard deviation were calculated.

Lipid peroxidation products from cells were measured by the thiobarbituric acid colorimetric assay. Briefly, an aliquot of the lysate $(100 \mu \mathrm{l})$ was added to $200 \mu \mathrm{l}$ of $10 \%(\mathrm{w} / \mathrm{v})$ trichloroacetic acid and, after centrifugation at 3,000 rpm for $10 \mathrm{~min}$, $260 \mu \mathrm{l}$ of $0.5 \%(\mathrm{w} / \mathrm{v})$ thiobarbituric acid were 
added and the mixture was heated at $80-100^{\circ} \mathrm{C}$ for 30 min. After cooling, malondialdehyde (MDA) formation was recorded by spectrophotometry at $550 \mathrm{~nm}$, in a microplate reader spectrophotometer (Bio-Rad). The results are presented as micromoles of MDA/ $\mu \mathrm{g}$ of cell protein determined by the BioRad protein assay. A standard curve of MDA was used to quantify the MDA levels formed during the experiments.

\section{Flow Cytometry Analysis}

HT-29 cells were plated at similar confluency, as described above, and after $24 \mathrm{~h}$, synchronized by a $48 \mathrm{~h}$ serum deprivation in $0.1 \%$ FBS. An aliquot of the cells was stimulated with 5,10 , or $20 \mu \mathrm{M}$ cladosporol A for different times $(4,8,12,24$, and $48 \mathrm{~h}$ ) in the presence of D-MEM containing $10 \%$ FBS. Another aliquot of cells was allowed to grow again in the complete medium; these samples were used as control. Afterwards, 2 millions of whole floating and adherent cells of each sample were collected, washed in cold calcium and magnesiumfree phosphate buffered saline (PBS), fixed and permeabilized in $70 \%$ cold ethanol for 30 min. Ethanol was removed by washing with PBS and cells were incubated in PBS containing $10 \mu \mathrm{g} / \mathrm{ml}$ deoxyribonuclease-free ribonuclease, for $10 \mathrm{~min}$, at $4^{\circ} \mathrm{C}$. Finally, $50 \mu \mathrm{g} / \mathrm{ml}$ PI was added and the cells were incubated at $4{ }^{\circ} \mathrm{C}$, overnight, in a dark room. Cells were analyzed by flow cytometry using a FACScan Flow Cytometer Apparatus $488 \mathrm{~nm}$ argon-laser (Becton Dickinson, Mountain View, CA). Analysis of the results was performed with CellFit DNA software (version 2.01.2 Becton Dickinson) run on HP series 9000 workstation Apollo OS Consort32 (Hewlett-Packard, Palo-Alto, CA). Width gating was performed to exclude doublets from $\mathrm{G} 2 / \mathrm{M}$ region on dot-plot. For each sample, 2,000 events were stored in list mode. The same experiment was performed also using p53+/+ and p53-/HCT116 cells.

\section{Western Blotting Analysis and Kinase Assay}

Treated and untreated cells were lysed in Ripa buffer $(150 \mathrm{mM} \mathrm{NaCl}, 50 \mathrm{mM}$ Tris- $\mathrm{HCl}, \mathrm{pH} 7.6$, $10 \mathrm{mM}$ EDTA, 1\% NP-40) containing also protease inhibitors cocktail and then centrifugated at $13,000 \mathrm{rpm}$ for $10 \mathrm{~min}$, at $4^{\circ} \mathrm{C}$. Supernatant containing total proteins was quantified and $80 \mu \mathrm{g}$ of each sample were separated on 12\% SDS-PAGE and transferred onto a PVDF membrane (Millipore, Bedford, MA) by electroblotting. Membranes were blocked in 5\% non-fat dry milk and probed with specific antibodies at $4^{\circ} \mathrm{C}$, overnight. After a 1 - $\mathrm{h}$ incubation with IgG-peroxidase-linked antibody, at room temperature, signals were detected by chemiluminescence with ECL or ECL Plus reagents. The relative intensity of protein bands was measured using the Molecular Imager Chemi-Doc imaging system (Bio-Rad) and evaluated by the Quantity One software (Bio-Rad).

To determine the histone H1-associated CDK2 kinase activity, $200 \mu \mathrm{g}$ of protein lysates from each sample was precleared with protein $A / G$ plus agarose beads and CDK2 was immunoprecipitated using a specific anti-CDK2 antibody $(2 \mu \mathrm{g})$ and protein $A / G$ plus agarose beads. The beads were washed three times with lysis buffer and finally twice with kinase assay buffer. Phosphorylation of histone $\mathrm{H} 1$ was measured by incubating the beads with $30 \mu \mathrm{g}$ of "hot" kinase solution $(4 \mu \mathrm{g}$ of histone $\mathrm{H} 1,1 \mu \mathrm{l}$ of $\gamma-{ }^{32} \mathrm{P}$-ATP, $0.5 \mu \mathrm{l}$ of $0.1 \mathrm{mM}$ of ATP and $24.5 \mu \mathrm{l}$ of kinase buffer) for $1 \mathrm{~h}$ at $37^{\circ} \mathrm{C}$. The reaction was stopped by boiling the samples in SDS sample buffer for $5 \mathrm{~min}$. The samples were analyzed by $12 \%$ SDS-PAGE and the gel was dried and subjected to autoradiography.

Reverse Transcription-PCR (RT-PCR) and Real-Time Quantitative PCR (RT-qPCR) Assays

RNA was isolated from treated and untreated HT-29 cells using TRIZOL reagent according to the manufacturer's instructions. The purity, integrity, and concentration of total RNA were determined by gel electrophoresis and UV spectroscopy. To obtain the cDNAs, $2 \mu \mathrm{g}$ of total RNA were reverse transcribed using SuperScript ${ }^{\mathrm{TM}}$ II reverse transcriptase. For each sample, total RNA was incubated with $2.5 \mu \mathrm{M}$ random primers at $70^{\circ} \mathrm{C}$, for $10 \mathrm{~min}$. After this step, a mixture containing $0.5 \mathrm{mM}$ dNTP, $10 \mathrm{mM}$ DTT, $5 \mathrm{U}$ of SuperScript ${ }^{\mathrm{TM}}$ II enzyme (Invitrogen, Carlsbad, CA) and First Strand buffer was added to the sample, which was incubated for $10 \mathrm{~min}$, at room temperature. Subsequently, the reaction proceeded at $42^{\circ} \mathrm{C}$, for $50 \mathrm{~min}$ and, finally, was stopped by incubation at $70^{\circ} \mathrm{C}$, for $15 \mathrm{~min}$. PCR analysis was performed for p2 $1^{\text {waf1/cip1 }}$ gene (351 bp amplicon) by using the following primers: 5'-GCGATGGAACTTCGACTTTGT-3' and $3^{\prime}$-GGGCTTCCTCTTGGAGAAGAT-5'. As an internal control for the densitometric analysis of the amplified fragments, the housekeeping human glyceraldehyde-3-phosphate dehydrogenase (GAPDH) gene (400 bp amplicon) was utilized by using the following primers: $5^{\prime}$-GACCCCTTCATTGACCTCAACTACATG-3' and 3'-GTGCACCACCCTGTTGCTGTA GCC-5'. PCR reaction was performed by adding to each sample a $20 \mu \mathrm{lmix}$ ture containing $2 \mu \mathrm{l}$ of the newly synthesized cDNA, PCR Buffer II, $1.5 \mathrm{mM} \mathrm{MgCl}_{2}, 0.2 \mathrm{mM}$ dNTP, $0.2 \mu \mathrm{M}$ primers, and $2.5 \mathrm{U}$ of AmpliTaq ${ }^{\mathbb{R}}$ Gold (Applied Biosystem, Foster City, CA). DNA amplification was carried out allowing 30 and 35 PCR cycles of reactions $\left(94^{\circ} \mathrm{C}\right.$ for $1 \mathrm{~min}, 58^{\circ} \mathrm{C}$ for $30 \mathrm{~s}$, $72^{\circ} \mathrm{C}$ for $1 \mathrm{~min}$, for each cycle). PCR products were analyzed on $1.2 \%$ agarose gels containing ethidium bromide. Gel images were acquired with the Chemi-Doc imaging system (Bio-Rad). 
For RT-qPCR, a $20 \mu \mathrm{l}$ mixture containing $1 \mu \mathrm{g}$ of cDNA, $10 \mu \mathrm{l}$ of SYBR Green and $0.4 \mu \mathrm{M}$ primers of p $21^{\text {WAF1/Cip1 }}$ or GAPDH was added to each sample. Thirty-five amplification cycles were performed according to the program used in RT-qPCR assay. For each sample, analysis was carried out in triplicate and the results were evaluated by the Gene Expression Relative Quantitation program (Bio-Rad).

Plasmids and Transient Transfection Experiments

The human wild-type $\mathrm{p} 21^{\text {waf1/cip } 1}$ promoterluciferase fusion construct (pWWP) and the mutants pWP124, pWP101, pWP101-mtSp1-3, pWP101mtSp1-4, pWP101-mtSp1-5/6 were a generous gift from Dr. Y. Sowa (Department of MolecularTargeting Cancer Prevention, Kyoto Prefectural University of Medicine, Kyoto, Japan) [35,36]. As an internal transfection control, we used the RSV$\beta G a l$ plasmid, expressing $\beta$-galactosidase cDNA driven by the strong Rous Sarcoma Virus (RSV) promoter.

The day before transient transfection, HT29 cells were plated in 12-well plates to reach a $70 \%$ confluence. After $24 \mathrm{~h}$, growth medium was replaced with OPTI-MEM ${ }^{\mathbb{R}}$ I, (Gibgo, Carlsbad, CA) without serum and antibiotics, and cells were transfected using lipofectamine 2000 reagent according to manufacturer's instructions. About 10-12 $\mathrm{h}$ after transfection, cells were washed and treated with $20 \mu \mathrm{M}$ cladosporol A. Transfection samples were carried out in triplicate and the transactivation activities were evaluated by luciferase assay. The achieved values were normalized by $\beta$-galactosidase assay and the average value for each triplicate was calculated.

\section{Bi-Dimensional Electrophoresis}

HT-29 cells were plated at 40\% confluence and treated or not with $20 \mu \mathrm{M}$ cladosporol A for $8 \mathrm{~h}$. Treated and untreated cells were collected into a buffer containing $8 \mathrm{M}$ urea, 4\% CHAPS, $40 \mathrm{mM}$ Tris, $65 \mathrm{mM}$ DTT and Protease Inhibitors cocktail, and lysed by three cycles of sonication at 70\% amplitude. After centrifugation at 13,000 rpm for $30 \mathrm{~min}$, at $4^{\circ} \mathrm{C}$, total proteins were extracted and quantified by spectroscopy at $595 \mathrm{~nm}$. For each sample, $200 \mu \mathrm{g}$ of total proteins were solubilized in a buffer with $8 \mathrm{M}$ urea, 2\% CHAPS, $100 \mathrm{mM}$ DTT, $0.5 \%$ ampholytes, and analyzed. For isoelectrofocusing, $7 \mathrm{~cm}$ strips with a $4-7 \mathrm{pH}$ range were used; strip rehydration proceeded for $16 \mathrm{~h}$. The focusing system was the IPG (GE Healthcare, Chalfont St. Giles, UK) and the program was set at an increasing voltage until $1,000 \mathrm{~V}$ for $1 \mathrm{~h}$ and then until $5,000 \mathrm{~V}$ for $160 \mathrm{~min}$, at $20^{\circ} \mathrm{C}$. Afterwards, the strips were equilibrated in $50 \mathrm{mM}$ Tris- $\mathrm{HCl}, \mathrm{pH}$ $8.8,2 \%$ SDS, $7 \mathrm{M}$ urea, $10 \%$ glycerol, $2 \%$ DTT, for $15 \mathrm{~min}$, and then incubated in $50 \mathrm{mM}$ Tris$\mathrm{HCl}$, pH 8.8, 2\% SDS, $7 \mathrm{M}$ urea, 10\% glycerol,
$2.5 \%$ iodoacetamide, bromophenol blue, for 15 min. Each strip was accommodated onto a $12 \%$ polyacrylamide gel and the proteins were separated at $120 \mathrm{~V}$, for $3 \mathrm{~h}$. Gels were fixed in $7 \%$ acetic acid, $50 \%$ methanol, for $15 \mathrm{~min}$, and stained with Gel Code Blue Stain reagent (Pierce, Thermo Fisher Scientific, Rockford, IL). Gels were scanned with a GS-800 calibrated densitometer (Bio-Rad) and analyzed by using the PD Quest v.6 software. The Spot Detection Wizard function allowed to optimize the spot determination parameters, to quantify relative intensity of all spots and evaluate statistical significance of the measured data. Spots intensities were obtained in pixel units and normalized to the total absorbance of the gel. Significance of differences between data was tested with the nonparametric Kolmogorov-Smirnov test. Since data were normally distributed, standard deviations of these distributions were a valid parameter to assess the significance of the quantitative differences measured. The maximal value of mean and median of logarithmic ratios of standard deviations was 0.1 , thus a threefold value of this parameter was used as a cut-off criterion to identify differentially expressed proteins. The increasing/ decreasing index (fold change) was calculated as ratio of averaged spot intensities (relative volumes) between the investigated and control maps. Two biological replicates of each sample and three technical replicates of each biological replicate were analyzed.

\section{In Gel Digestion and Mass Spectrometry (MS) Analysis}

Spots were manually excised from gels, triturated and washed with water. Proteins were in-gel reduced, S-alkylated and digested with trypsin as previously reported [37]. Digest aliquots were removed and subjected to a desalting/concentration step on $\mu$ ZipTipC18 (Millipore) using 5\% formic acid/50\% acetonitrile as eluent before MALDI-TOFMS or nanoLC-ESI-LIT-MS/MS analysis.

In the first case, peptide mixtures were loaded on the MALDI target, using the dried droplet technique and $\alpha$-cyano-4-hydroxycinnamic acid as matrix, and analyzed by a Voyager DE PRO mass spectrometer (Applied Biosystems, Framingham, MA), operating in positive ion reflectron mode, with an acceleration voltage of $20 \mathrm{kV}$, a nitrogen laser $(337 \mathrm{~nm})$ and a laser repetition rate of $4 \mathrm{~Hz}$. The final mass spectra, measured over a mass range of 800-4,000 Da and by averaging 50-300 laser shots, were elaborated using the DataExplorer 5.1 software (Applied Biosystems) and manually inspected to get the corresponding peak lists. Internal mass calibration was performed with peptides deriving from trypsin autoproteolysis.

In the second case, after removing acetonitrile by concentration, digests were analyzed by nanoLC-ESI-LIT-MS/MS using a LTQ XL mass 
spectrometer (Thermo Finnigan, San Jose, CA) equipped with Proxeon nanospray source connected to an Easy-nanoLC (Proxeon, Odense, Denmark). Peptide mixtures were separated on an Easy C18 column $(10 \times 0.075 \mu \mathrm{m}, 3 \mathrm{~mm})$ (Proxeon, Odense, Denmark) using a linear gradient from $5 \%$ to $50 \%$ of acetonitrile in $0.1 \%$ formic acid, over $60 \mathrm{~min}$, at a flow rate of $300 \mathrm{nl} / \mathrm{min}$. Spectra were acquired in the range $m / z$ 400-2000. Acquisition was controlled by a data-dependent product ion scanning procedure over the three most abundant ions, enabling dynamic exclusion (repeat count 2 and exclusion duration $1 \mathrm{~min}$ ). The mass isolation window and collision energy were set to $\mathrm{m} / \mathrm{z} 3$ and $35 \%$, respectively.

\section{Protein Identification}

MASCOT software package (Matrix Science, UK) was used to identify spots unambiguously from an updated plant non-redundant sequence database (NCBI nr 2009/05/03) in MALDI-TOF peptide mass fingerprinting experiments by using a mass tolerance value of $40-80 \mathrm{ppm}$, trypsin as proteolytic enzyme, a missed cleavages maximum value of 2 and Cys carbamidomethylation and Met oxidation as fixed and variable modification, respectively. Candidates with a MASCOT score $>82$, corresponding to $P<0.05$ for a significant identification, were further evaluated by the comparison with their calculated mass and pI values, using the experimental values obtained from 2 -DE.

MASCOT software package (Matrix Science, UK) was also used to identify spots unambiguously from the same updated plant non-redundant sequence database (NCBI nr 2009/05/03) in nanoLCESI-LIT-MS/MS experiments by using a mass tolerance value of 2 Da for precursor ion and 0.8 Da for MS/MS fragments, trypsin as proteolytic enzyme, a missed cleavages maximum value of 2 and Cys carbamidomethylation and Met oxidation as fixed and variable modification, respectively. Candidates with more than two assigned peptides with an individual MASCOT score $>25$, corresponding to $P<0.05$ for a significant identification, were further evaluated by the comparison with their calculated mass and pI values, using the experimental values obtained from 2-DE. Where appropriate, protein identification was checked manually to provide for a false positive rate $<1 \%$.

\section{Statistical Analysis}

All experiments were performed at least three times. Data from viability and lipid peroxidation assays, flow cytometry, Western blotting, RT-PCR, and transient transfection experiments were expressed as means \pm SD. Statistical significance was determined by Student's test comparison between two groups of data sets. Asterisks reported in the figures show the differences of experimental groups in comparison with the corresponding control condition $(P<0.05$, for example).

\section{RESULTS}

Cladosporol A Inhibits the Growth of Different Human CRC Cell Lines

To examine the effects of cladosporol A on cell growth, we initially treated colon carcinoma HT29 cells for $72 \mathrm{~h}$ with increasing concentrations of the compound. Cell survival was reduced as evaluated by the CellTiter Aqueous One Cell Proliferation Assay (Figure 1B). The $\mathrm{IC}_{50}$ values of cladosporol A on HT-29 cells were 13.85, 12.35, and $6.9 \mu \mathrm{M}$ following a 24, 48, and $72 \mathrm{~h}$ treatment, respectively. On the basis of these values, we tested the antiproliferative effect of cladosporol A on two additional CRC derived cell lines, CaCo2, SW480, in parallel with HT-29. Cells were treated with increasing amounts of cladosporol A for $24 \mathrm{~h}$ and their proliferation rate was reduced in a dose-dependent manner (Figure 2A). HT-29 showed a more evident growth inhibition than SW480 and CaCo-2 cells and were analyzed in details in the following experiments. We then treated HT-29 cells with increasing concentrations of cladosporol A, for 4, 8, 24, and $48 \mathrm{~h}$. The number of surviving cells diminished in a dose- and time-dependent manner, as compared to untreated cells (Figure 2B). Cladosporol A did not exert a generic cytotoxic effect on HT-29 cells because inhibition was reverted following drug withdrawal. Growth recovery was even more evident when cells were treated for 24 or $48 \mathrm{~h}$ with the drug $(5 \mu \mathrm{M})$ and then left in culture for additional $96 \mathrm{~h}$ in the absence of the drug (Supplementary data1). These results are consistent with those reported by Chen et al. [33] who showed no toxicity induced by cladosporol in gastric cancer cells xenografted into nude mice. Finally, cladosporol A-treated cells detached from the plate surface with a typical rounded-up morphology as observed with a light transmission microscope (Figure 2C). All together, these findings indicate that cladosporol $\mathrm{A}$ inhibits the proliferative capacity of various CRC tumor cell lines, among which HT-29 cells were the most susceptible to treatment.

\section{Cladosporol A Induces a G1-Phase Growth Arrest During} the Cell Cycle

To determine the cell cycle changes underlying the growth inhibition found, the nuclear DNA content of HT-29 cells at the different phases of the cell cycle was analyzed by flow cytometry in the absence or presence of cladosporol A. HT29 cells were cultured in proliferating medium for $24 \mathrm{~h}$ and, subsequently, synchronized by serum starvation for $48 \mathrm{~h}$. Cells were then grown in a medium containing $10 \%$ FBS and different 
A

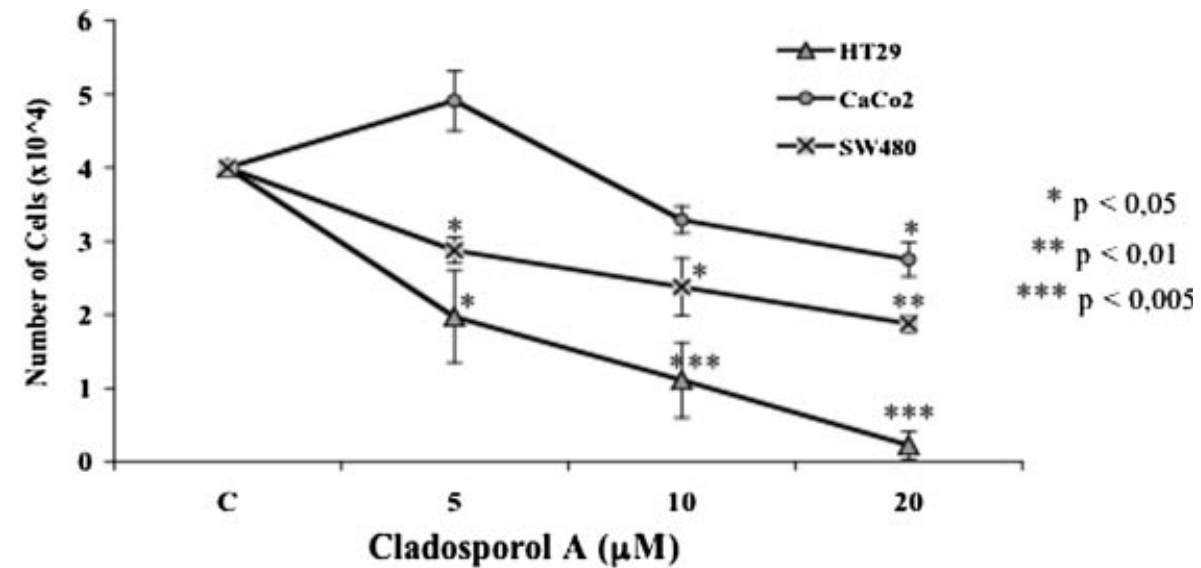

B

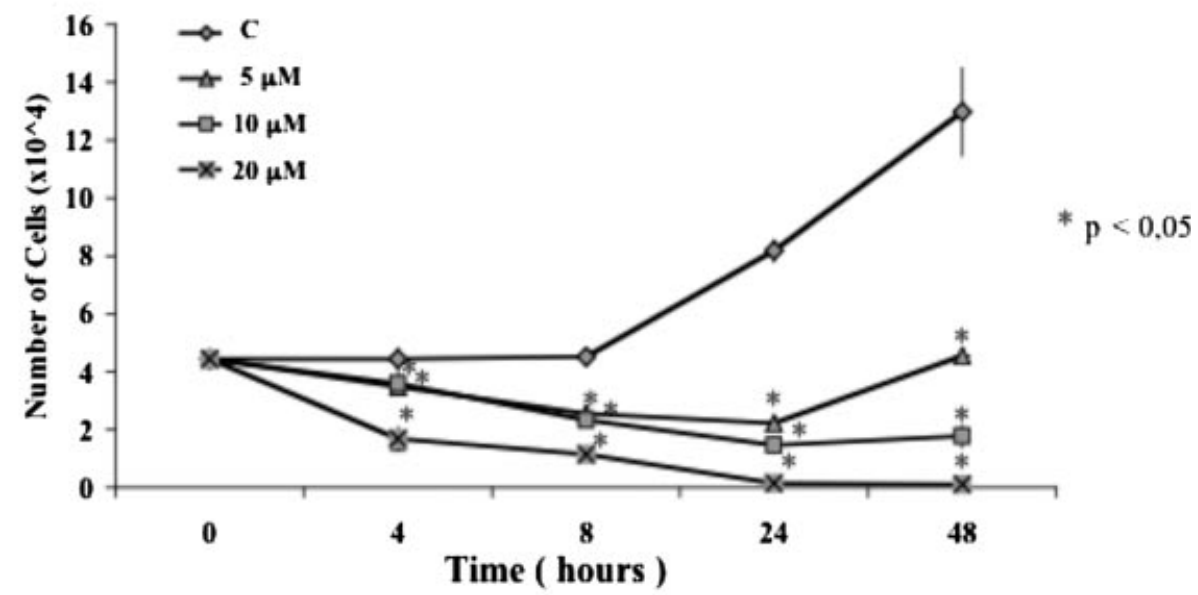

C

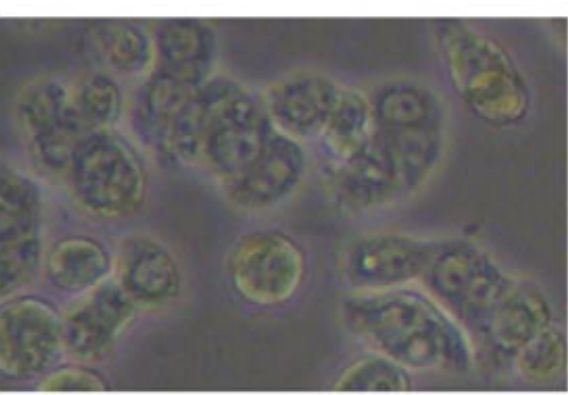

Untreated

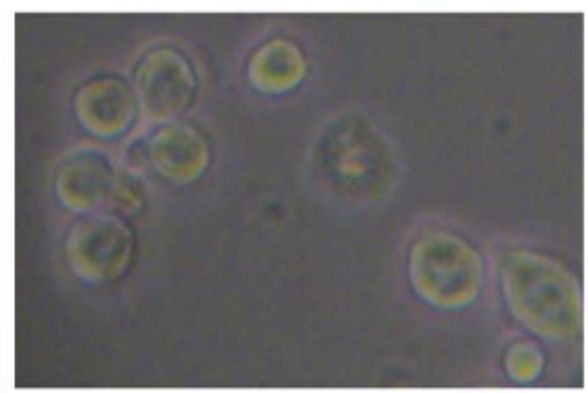

$10 \mu \mathrm{M}$

Figure 2. Cladosporol A inhibits cell growth in a dose- and time-response manner. (A) To assess the effect of cladosporol A on esponentially growing HT-29, CaCo-2, and SW480 cells, cells were treated with different doses of cladosporol $A(5,10$, and $20 \mu \mathrm{M})$. After $24 \mathrm{~h}$, cells were collected and counted. The data shown here are mean \pm SD of three experiments performed in duplicate. Results were similar in two independent experiments. ${ }^{*} P<0.05 ;{ }^{* *} P<0.01 ;{ }^{* * *} P<0.005$ when compared with control. (B) To assess the effect of cladosporol $A$ on esponentially

Molecular Carcinogenesis

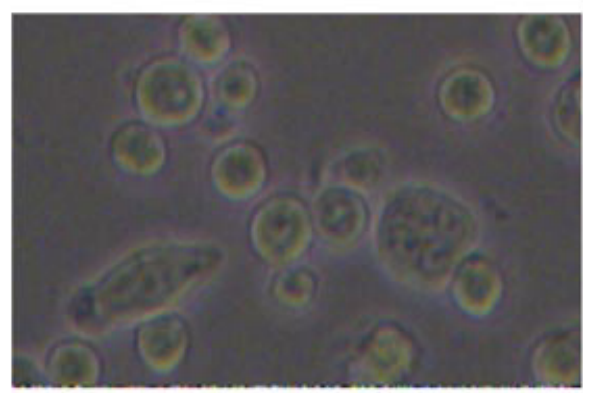

$5 \mu \mathbf{M}$

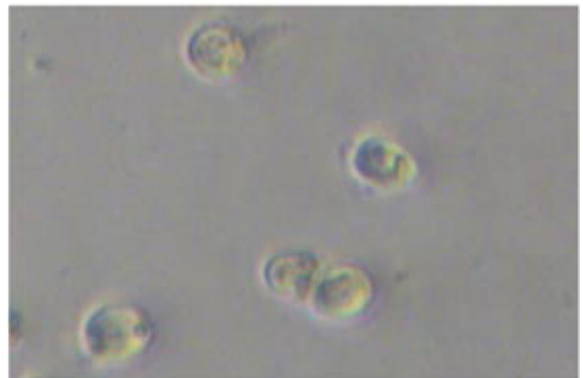

$20 \mu \mathrm{M}$

growing HT-29 cells, cells were treated or not with 5,10 , and $20 \mu \mathrm{M}$ cladosporol A, for $4,8,24$, and $48 \mathrm{~h}$. Then, cells were collected and counted. The data shown here are mean \pm SD of three experiments performed in duplicate. Results were similar in two independent experiments. ${ }^{*} P<0.05$ when compared with control. (C) Morphological changes of HT-29 cells treated or not with 5,10 , and $20 \mu \mathrm{M}$ cladosporol A. Pictures were taken using light trasmission microscopy at a magnification of $10 \times$. 
concentrations of cladosporol A. Exposure to 5$10 \mu \mathrm{M}$ of the compound determined a significant increase in the G2/M cell population and a concomitant decrease in the G1-phase cells with respect to untreated cells (Figure 3A). Specifically, treatment with 5 and $10 \mu \mathrm{M}$ cladosporol A for $24 \mathrm{~h}$ resulted in $29.45 \%$ and $34.45 \%$ of $\mathrm{G} 2 / \mathrm{M}$ cells, respectively, as compared to $19.1 \%$ of control cells (Table 1). Exposure to $20 \mu \mathrm{M}$ cladosporol A, surprisingly, caused a significant increase of G1 cells and a parallel decrease of the $S$ and $G 2 / M$ cell
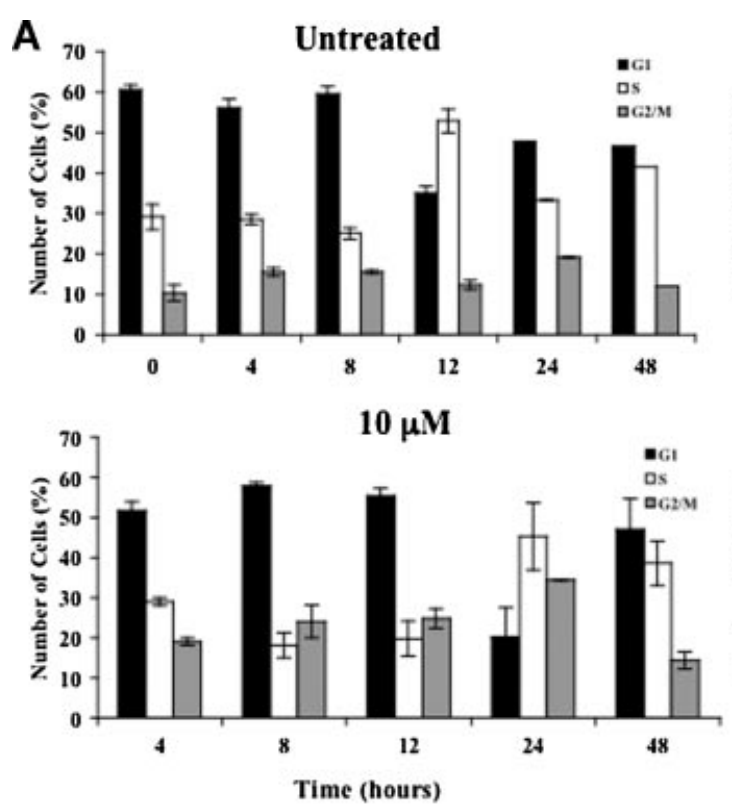

B

$5 \mu \mathrm{M}$

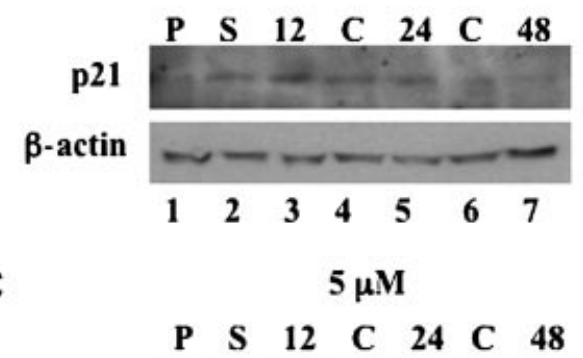

Cyclin D1

$\begin{array}{lllllll}P & S & 12 & \text { C } & 24 & \text { C } & 48\end{array}$

\section{B-actin}

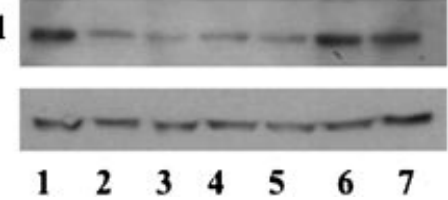

Figure 3. Cladosporol A suppresses HT-29 cells via G1-phase arrest. (A) Cell cycle distribution in HT-29 cells, firstly synchronized by serum deprivation and then treated or not with 5,10 , and $20 \mu \mathrm{M}$ cladosporol A, for 4, 8, 12, 24, and $48 \mathrm{~h}$. 'Data are mean \pm SD of three different experiments performed in duplicate. (B) Western blotting analysis on total protein extracts produced from HT-29 cells treated or not with 5 and $20 \mu \mathrm{M}$ cladosporol A for 12,24 , and $48 \mathrm{~h}$. Anti-p2 $1^{\text {waf1/cip } 1}$ was used to probe untreatfor 12,24 , and $48 \mathrm{~h}$. Anti-p21 and cladosporol A-treated HT-29 cells. Lane 1: proliferating cells; lane 2: serum-deprived cells. In lanes 4 and 6 of left panel and lanes 3, 5 and 7 of the right panel are reported the results population. The percentage of G1 cells was $60.2 \%$ at $12 \mathrm{~h}$ and $57.1 \%$ at $24 \mathrm{~h}$ as compared to $34.9 \%$ and $47.65 \%$ in control cells, respectively (Table 1 ). Cladosporol A then affects HT-29 cell proliferation ability through a cell cycle arrest at the G2/M phase at $5-10 \mu \mathrm{M}$ or at the G1 phase at higher dosages.

We next examined whether the cell cycle arrest was associated with changes in the expression of specific proteins involved in its control (Figure 3B,C). To this aim, total protein extracts
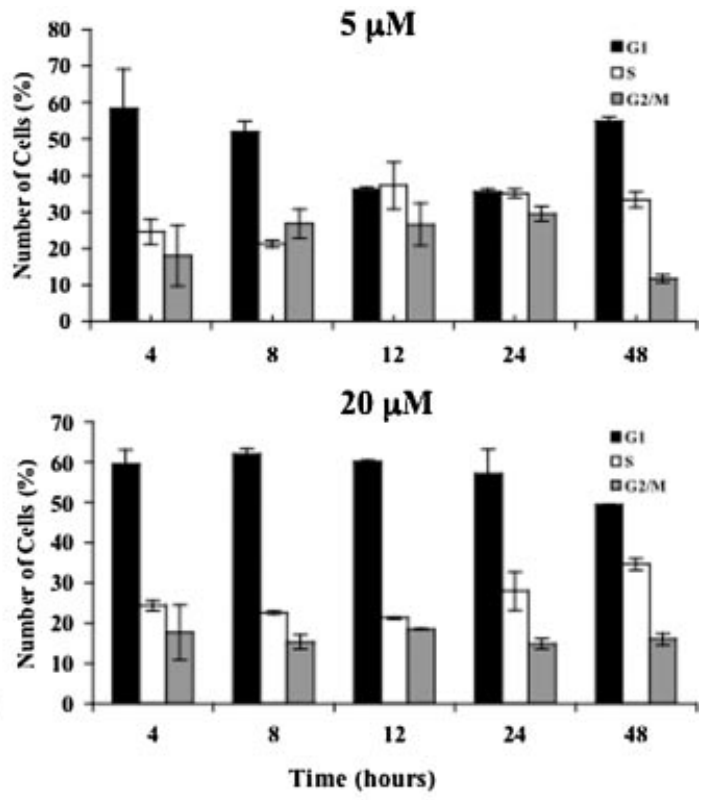

$20 \mu \mathrm{M}$

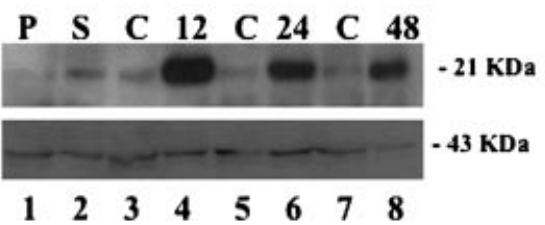

$20 \mu \mathrm{M}$

$\begin{array}{lllllll}P & S & 12 & \text { C } & 24 & \text { C } & 48\end{array}$

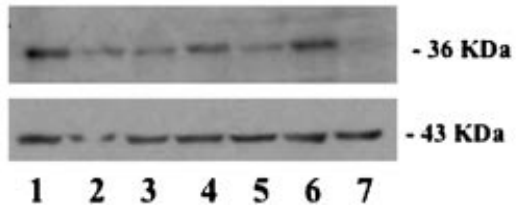

from untreated HT-29 cells. In lanes 3,5 and 7 of left panel and lanes 4,6 , and 8 of right panel are reported the results from HT29 cells treated with the specific dosages for the indicated times. (C) The same samples of (B) were tested by Western blotting experiments with an anti-cyclin D1 antibody. Lane 1: proliferating cells; lane 2: serum-deprived cells. In lanes 4 and 6 of left and right panels are reported the results from untreated HT-29 cells. In lanes 3,5 , and 7 of left and right panels are reported the results from HT-29 cells treated with the specific dosages for the indicated times. To normalize the samples loaded on the gel, Western blotting with an anti- $\beta$-actin antibody was carried out. 
Table 1. The Percentage of HT-29 cells in Each Population During the Cell Cycle is Reported as the Mean \pm SD of Three Different Experiments Performed in Duplicate

\begin{tabular}{|c|c|c|c|c|c|c|}
\hline & $\mathrm{Oh}$ & $4 \mathrm{~h}$ & $8 \mathrm{~h}$ & $12 \mathrm{~h}$ & $24 \mathrm{~h}$ & $48 \mathrm{~h}$ \\
\hline \multicolumn{7}{|l|}{ Untreated } \\
\hline G0/G1 & $60.6 \pm 1.1$ & $56.5 \pm 2.25$ & $59.55 \pm 1.75$ & $34.9 \pm 1.9$ & $47.65 \pm 0.15$ & $-16.55 \pm 0.65$ \\
\hline$S$ & $29.1 \pm 3.1$ & $28.45 \pm 1.2$ & $25.04 \pm 1.4$ & $52.8 \pm$ & $33.2 \pm 0.00$ & $41.5 \pm 0.2$ \\
\hline $\begin{array}{l}\text { G2/M } \\
5 \mu M\end{array}$ & $10.3 \pm 2$ & $15.5 \pm 1$ & $15.45 \pm 0.45$ & $12.3 \pm 1.1$ & $19.1 \pm 0.1$ & $12.0 \pm 0.5$ \\
\hline $\mathrm{GO} / \mathrm{G} 1$ & $60.6 \pm 1.1$ & $58.25 \pm 10.85$ & $51.9 \pm 3$ & $36.15 \pm 0.65$ & $35.5 \pm 0.9$ & $54.9 \pm 1.1$ \\
\hline$S$ & $29.1 \pm 3.1$ & $24.6 \pm 3.4$ & $21.25 \pm 0.95$ & $37.2 \pm 6.5$ & $35.1 \pm 1.2$ & $33.35 \pm 2.15$ \\
\hline G2/M & $10.3 \pm 2$ & $18.05 \pm 8.35$ & $26.85 \pm 3.95$ & $26.6 \pm 5.8$ & $29.45 \pm 2.05$ & $11.75 \pm 1.05$ \\
\hline G0/G1 & $60.6 \pm 1.1$ & $51.75 \pm 2.25$ & $57.85 \pm$ & $55.4 \pm 1.9$ & $20.3=$ & $47 \pm 7.7$ \\
\hline S & $29.1 \pm 3.1$ & $29 \pm 1$ & $18.1 \pm$ & $19.8 \pm 4.4$ & 45.3 & $38.6 \pm 5.5$ \\
\hline G2/M & $10.3 \pm 2$ & $19.05 \pm 0.95$ & $24.05 \pm 4.05$ & $24.8 \pm 2.5$ & $34.45 \pm 0.15$ & $14.4 \pm 2.2$ \\
\hline Go/G1 & $60.6 \pm 1.1$ & $59.65 \pm 3.55$ & $62 \pm 1.4$ & $36.15 \pm 0.65$ & $35.5 \pm 0.9$ & $54.9 \pm 1.1$ \\
\hline & $29.1 \pm 3.1$ & $24.35 \pm 1.25$ & $22.65 \pm 0.35$ & $52.8 \pm 3$ & $33.2 \pm 0.00$ & $41.5 \pm 0.2$ \\
\hline G2/M & $10.3 \pm 2$ & $17.7 \pm 6.8$ & $15.35 \pm 1.75$ & $18.5 \pm 0.00$ & $14.9 \pm 1.3$ & $16 \pm 1.5$ \\
\hline
\end{tabular}

For all treated samples $P$-values were calculated $(P<0.05$ when compared with control).

from HT-29 proliferating (lane 1), serum-deprived (lane 2), treated with $5 \mu \mathrm{M}$ (lanes 3, 5, and 7, left panel) and $20 \mu \mathrm{M}$ cladosporol A (lanes 4,6 , and 8 , right panel), for 12,24 , and $48 \mathrm{~h}$, were probed for p21 $1^{\text {waf1/cip } 1}$ by Western blotting and compared to untreated control cells (lanes 4 and 6 for the $5 \mu \mathrm{M}$ dosage, left panel; lanes 3, 5, and 7 for the $20 \mu \mathrm{M}$ dosage, right panel). p21 $21^{\text {waf1/cip1 }}$ was expressed at high levels in HT-29 cells treated with $20 \mu \mathrm{M}$ cladosporol A for $12 \mathrm{~h}$ (Figure 3B, right panel lane 4), and only modestly in proliferating cells (lane 1) and corresponding controls at 12, 24, and $48 \mathrm{~h}$ (lanes 3, 5 and 7). The expression remained elevated in cells exposed to $20 \mu \mathrm{M}$ cladosporol A for 24 and $48 \mathrm{~h}$ (lanes 6 and 8), although progressively diminished, suggesting degradation events. In serum-deprived cells, p21 waf1/cip1 expression was only slightly increased, as expected (lane 2). Cyclin D1 expression was lower in cells treated for 24 and $48 \mathrm{~h}$ with $20 \mu \mathrm{M}$ cladosporol A (lanes 5 and 7) than the untreated controls (lanes 4 and 6), confirming the specific G1-phase block (Figure 3C, right panel). No changes in p21 $1^{\text {waf1/cip } 1}$ or cyclin D1 protein expression were observed in HT-29 cells exposed to $5 \mu \mathrm{M}$ cladosporol $\mathrm{A}$, in agreement with the flow cytometry data (see Figure $3 \mathrm{~A}-\mathrm{C}$ ). Thus, the treatment with $20 \mu \mathrm{M}$ cladosporol A causes a G1 phase arrest as documented by the increase in p21 $1^{\text {waf1/cip } 1}$ expression and the simultaneous decrease of cyclin D1.

Cladosporol A Influences the Expression of Cell Cycle Regulators in Proliferating HT-29 Cells

We then treated proliferating HT-29 cells for different times with increasing concentrations of cladosporol A and assessed the expression of specific proteins involved in cell-cycle control. Expression of $\mathrm{p} 21^{\text {waf1/cip } 1}$, cyclin $\mathrm{A}$ and $\mathrm{B} 1$, specific markers of G1, S, and G2/M phases, respectively, was investigated by Western blotting assay. Exposure to $5-10 \mu \mathrm{M}$ cladosporol A for 4 and $8 \mathrm{~h}$, resulted in a modest increase of $\mathrm{p} 21^{\mathrm{waf} 1 / \mathrm{cip} 1}$, whereas the treatment with $20 \mu \mathrm{M}$ cladosporol $\mathrm{A}$, for the same times, caused a robust accumulation of $\mathrm{p} 21^{\text {waf1/cip1 }}$ (Figure 4). From $8 \mathrm{~h}$ of treatment, p21 ${ }^{\text {waf1/cip } 1}$ started to decline to reach undetectable levels at $48 \mathrm{~h}$. Cyclin B1 expression increased in a dose $(5,10$, and $20 \mu \mathrm{M})$ and time dependent manner $(4,8$, and $24 \mathrm{~h})$, recovering the control levels at $48 \mathrm{~h}$. Cyclin A expression, on the contrary, rapidly diminished already at $4 \mathrm{~h}$ of treatment with 5 , 10 , and $20 \mu \mathrm{M}$ cladosporol $\mathrm{A}$, with no detectable variations at 8,24 , and $48 \mathrm{~h}$.

Since p21 $21^{\text {waf1/cip } 1}$ accumulates in proliferating HT-29 cells after only $4 \mathrm{~h}$ of cladosporol A exposure, we next investigated whether other cell cycle regulators were affected under the same experimental conditions. Cells were treated with $20 \mu \mathrm{M}$ cladosporol A, for 4,6 , and $8 \mathrm{~h}$, and protein extracts analyzed by Western blotting for different cell cycle gatekeepers (Figure 5A-I). In addition to the growth arrest, accumulation of $\mathrm{p} 21^{\text {waf } 1 / \mathrm{cip} 1}$ protein (about twofold as compared to control) and progressive decrease of cyclin D1 as shown above, cyclin B1 showed a light increase while Cdc2-p34 and PCNA slightly decreased suggesting a partial accumulation of cells at the G2/M phase. This block occurred even if the treatment with $20 \mu \mathrm{M}$ cladosporol A was associated with a G1 phase arrest. Moreover, cyclin E, CDK2, CDK4 also showed 
Figure 4. Effect of cladosporol $A$ on the cell cycle regulators expression in proliferating HT-29 cells treated or not with 5,10 , and $20 \mu \mathrm{M}$ cladosporol A, for 4, 8, 24, and $48 \mathrm{~h}$. Different antibodies against p2 $1^{\text {waf } 1 / \mathrm{cip} 1}$, cyclin $\mathrm{B} 1$ and cyclin $\mathrm{A}$, three modulators of $\mathrm{G} 1, \mathrm{~S}$, and G2/M phases, respectively, were used in the Western blotting analysis. To control the samples loaded derived from untreated and cladosporol A-treated HT-29 cells, an anti$\beta$-actin antibody was used. Cells were treated with the specific dosages for the indicated times.

a time-dependent decrease indicating that inhibition of cyclinD1/CDK4 and cyclinE/CDK2 complexes might explain the cladosporol A-induced G1 phase cell cycle arrest (Figure 5F-H). As shown in Figure 5L, treatment of HT-29 cells with $20 \mu \mathrm{M}$ of cladosporol A resulted in a reduction in histone H1-associated CDK2 activity that could be due to the cyclin E and CDK2 decrease, and simultaneous increase of cyclinE/CDK2 complex binding to CDKIs, that is, p21 waf1/cip1. Lastly, RB, which is the target of the cyclinD1/CDK4, showed a significant reduction after cladosporol A treatment, suggesting a diminished availability to the binding with cyclinD1/CDK4 complex (Figure 5I). Together, these results indicate that cladosporol $\mathrm{A}$ is responsible for the changes in cell cycle regulators not only in synchronized, but also in proliferating HT-29 cells and, remarkably, that the cladosporol A-induced G1 phase cell cycle arrest in HT-29 cells could be sequentially caused by induction of CDKIs (p21 waf1/cip1 $)$, a decrease of G1 phase cyclins and CDKs and, finally, a decrease in the histone H1-associated CDK2 kinase activity.

Cladosporol A Up-regulates p2 $1^{\text {waf1/cip } 1}$ Transcription in HT-29 Cells

To investigate whether the $\mathrm{p} 21^{\text {waf1/cip } 1}$ increase was due to a gene transcription activation, total RNA was extracted from HT-29 cells treated with $20 \mu \mathrm{M}$ cladosporol $\mathrm{A}$, for $1,2,4$, and $8 \mathrm{~h}$, and analyzed by semiquantitative RT-PCR. The p21 waf1/cip1 specific amplicon showed a sharp increase after $2 \mathrm{~h}$ reaching a plateau at 4 and $8 \mathrm{~h}$ (Figure 6A). Similar results were obtained by carrying out longer PCR assays (30 vs. 35 cycles) (Figure 6B). A more accurate analysis by RT-qPCR further supported these results as illustrated in Figure 6C.

To confirm that cladosporol A induces a more efficient $\mathrm{p} 21^{\text {waf1/cip1 }}$ gene transcription, we transiently transfected proliferating HT-29 cells with a recombinant plasmid (pWWP) bearing the entire $\mathrm{p} 21^{\text {waf1/cip } 1}$ human gene promoter, a 2,320 bp long fragment, fused upstream to the luciferase reporter gene [38]. Exposure of transfected HT-29 cells to $20 \mu \mathrm{M}$ of cladosporol A caused an increase in luciferase activity as compared to untreated cells (Figure 6D). Note that no luciferase activity was detected at higher cladosporol A concentrations indicating that transcription inhibition is likely due to a drug saturation effect. As a positive control, an aliquot of transfected cells was exposed to $10 \mu \mathrm{M}$ troglitazone, a member of the thiazolidinediones (TZD) family of PPAR $\gamma$ specific ligands. In fact, it is known that the human $\mathrm{p} 21^{\text {waf1/cip } 1}$ gene is positively regulated through the interaction of the transcription factor Sp1 with PPAR $\gamma \nabla$ a member of the orphan nuclear receptors family [38-40], particularly in thyroid cells [41].

To investigate whether the Sp1 binding sites located in proximal promoter play any role in mediating cladosporol A-induced p21 waf1/cip1 gene transcription, we transiently transfected a reporter construct (pWP124) that includes only the more proximal $124 \mathrm{bp}$ of the $\mathrm{p} 21^{\text {waf1/cip } 1}$ promoter and no longer carries the two p53 binding sites located at position -2301 and -1394 and the two RXR motifs at -1221 (RXRE1) and -1198 (RXRE2), respectively (Figure 6E). Luciferase activity in cells treated with cladosporol A was higher than that observed in cells transfected with the reporter plasmid carrying the entire promoter (pWWP), suggesting that the transcriptional efficiency of the human $\mathrm{p} 21^{\text {waf1/cip } 1}$ promoter depends on the presence of the Sp1 binding motifs located within the proximal promoter. Neither the binding of $\mathrm{p} 53$ nor that of RXR to their cognate motifs in the more upstream promoter appear to be required for cladosporol A-induced p21 waf1/cip1 transcription.

To understand the relative contribution of the Sp1 binding sites to gene activation, we transiently transfected recombinant plasmids in which the Sp1 binding sites were either deleted or sitedirected mutated (Figure 6E). Plasmid pWP101, carrying a shorter version of the $\mathrm{p} 21^{\text {waf1/cip } 1}$ promoter in which the two more upstream Sp1 
A

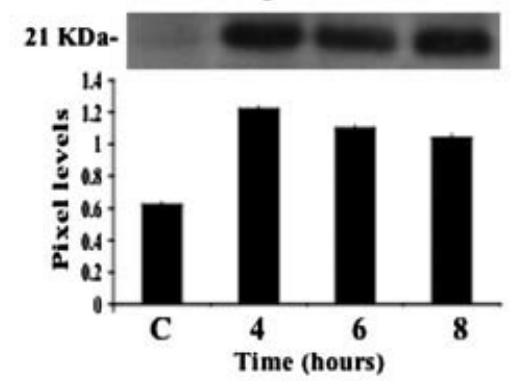

C
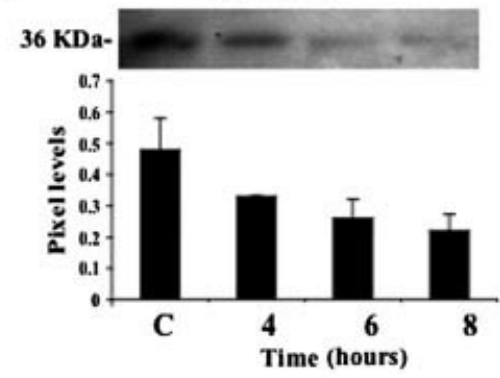

$\mathbf{E}$
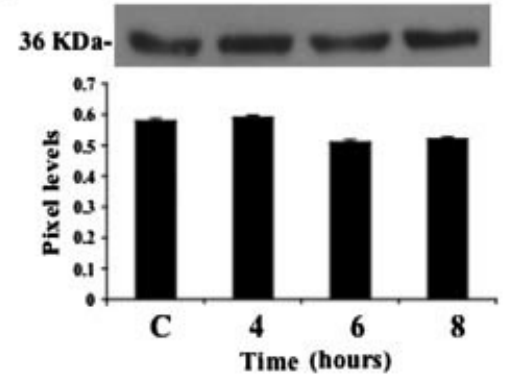

G

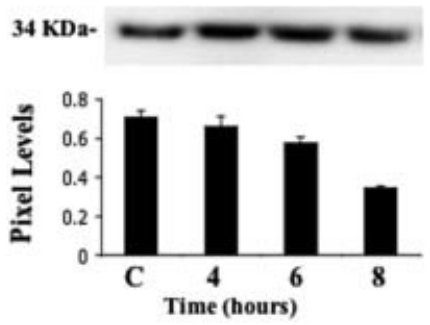

I

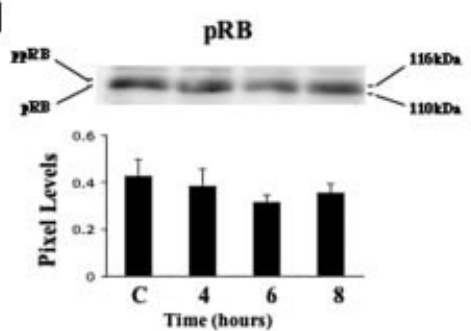

Figure 5. Quantitative evaluation of the cladosporol A-induced expression of the cell cycle regulators in proliferating HT-29 cells. Cells were treated or not with $20 \mu \mathrm{M}$ cladosporol A, for 4, 6, and $8 \mathrm{~h}$. Cell lysates were prepared in non-denaturing lysis buffer and then analyzed by Western blotting using anti-p21waf1/cip1 (A), anticyclin B1 (B), anti-cyclin D1 (C), anti-Cdc2-p34 (D) anti-PCNA (E) anti-cyclin $E(F)$, anti-CDK2 $(\mathrm{G})$, anti-CDK4 $(\mathrm{H})$, anti-RB (I) antibodies. To control the samples loaded derived from untreated and cladosporol A-treated HT-29 cells, an anti- $\beta$-actin antibody was used. The bar graphs represent the mean \pm SD of proteins $/ \beta$-actin
B

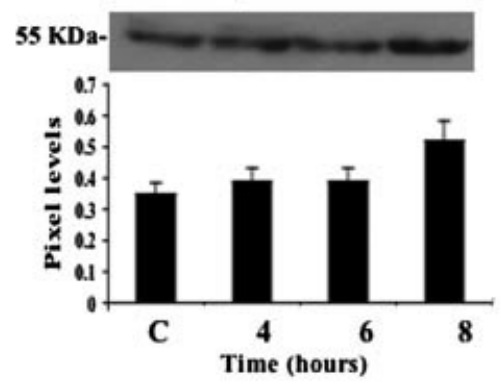

D

Cdc2-p34

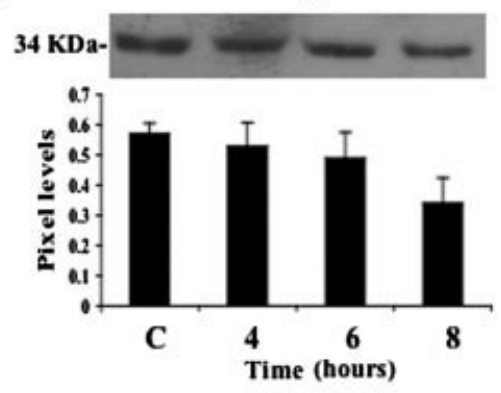

F

Cyclin E

55 KDa-

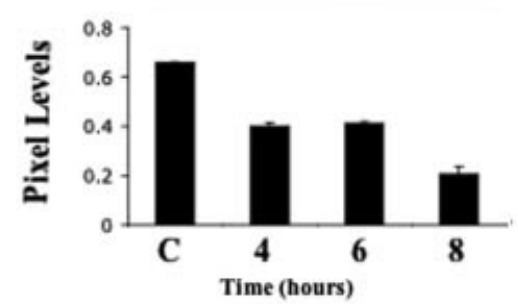

H

CDK4

$34 \mathrm{KDa}-$

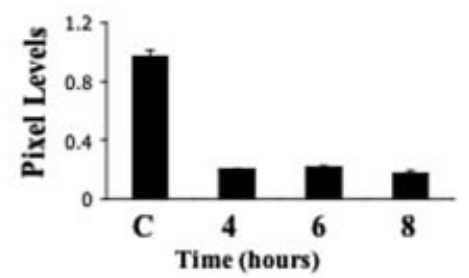

L $20 \mu \mathrm{M}$ Cladosporol A (hours of treatment:

IP: anti-CDK2

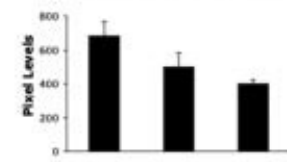

of at least three independent experiments. The Western blotting assays reported here are representative of a single exemplificative experiment. (L) Histone $\mathrm{H} 1$-associated CDK2 kinase activity assay in proliferating HT-29 cells. Cells were treated with $20 \mu \mathrm{M}$ cladosporol A for the indicated times and then total cell lysates of each sample were immunoprecipitated with anti-CDK2 antibody. The kinase reaction was performed using histone $\mathrm{H} 1$ as substrate of kinase reaction was performed using histone $\mathrm{H} 1$ as substrate of
cyclin E/CDK2 complex. The bar graphs represent the mean \pm SD of at least three independent experiments, while the assay reported here is representative of a single exemplificative experiment. 
A

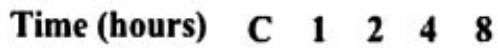

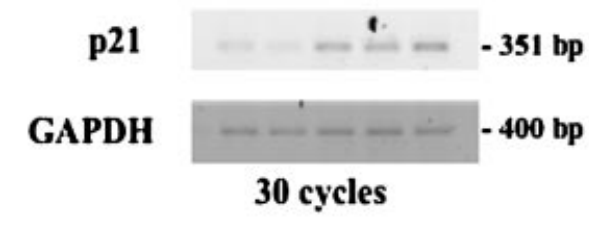

C

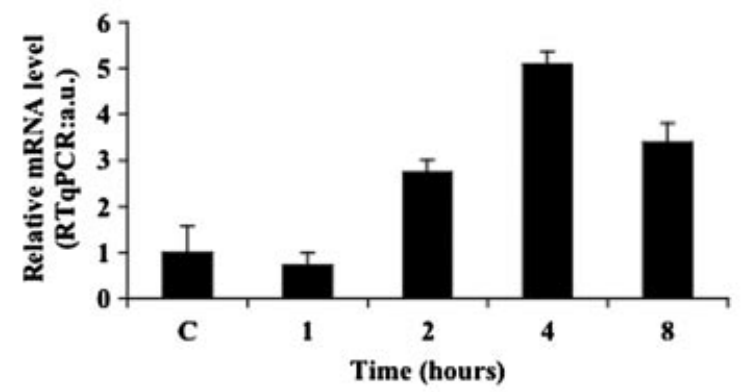

E

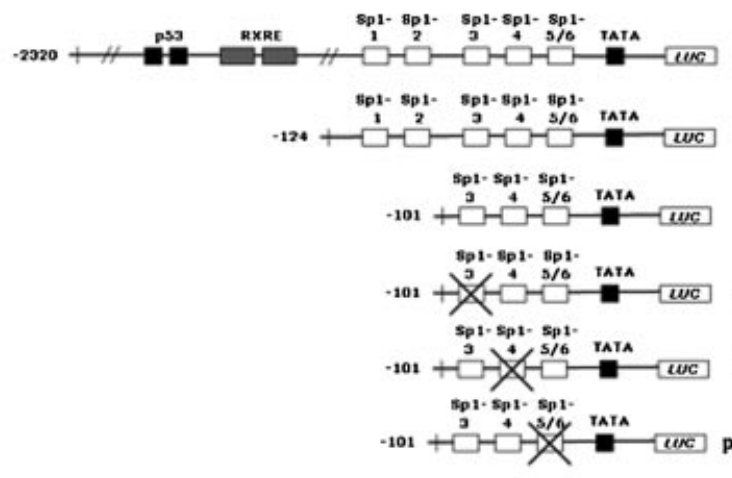

B

Time (hours) $\quad$ C $11 \quad 2 \quad 4 \quad 8$

p21

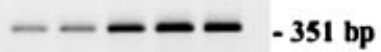

GAPDH

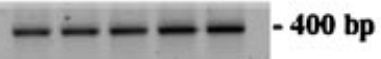

35 cycles
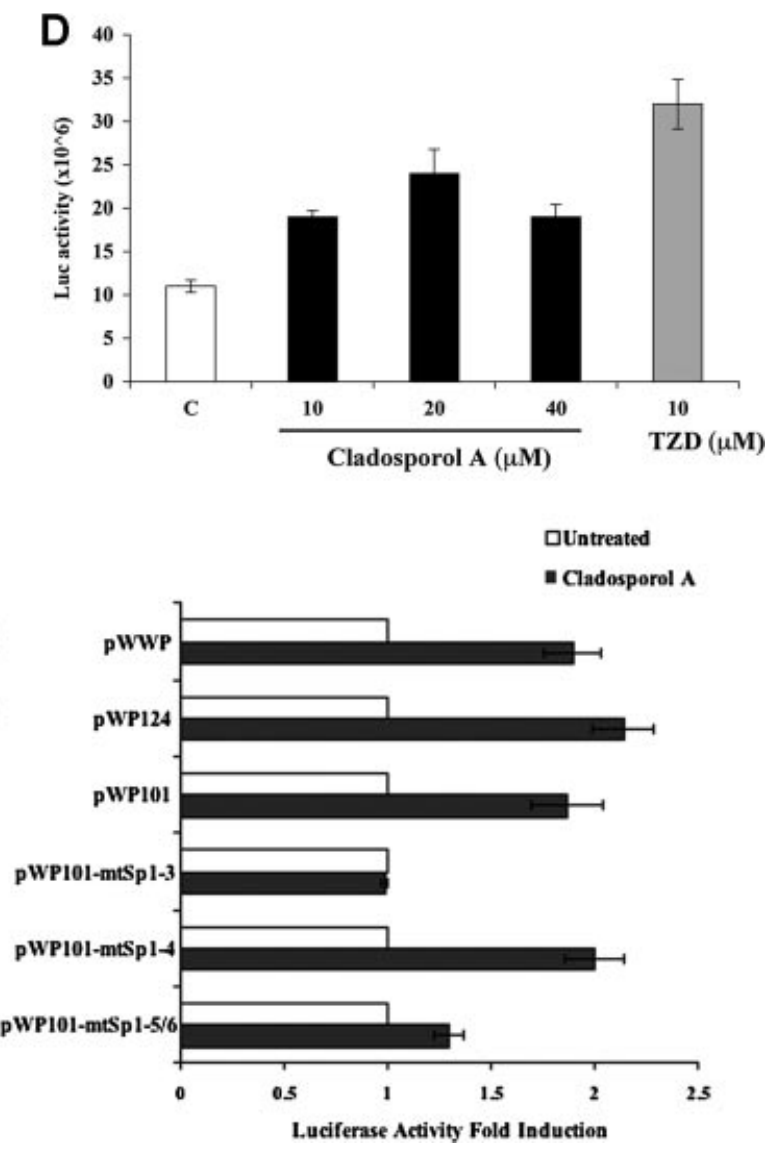

treated with 10,20 , and $40 \mu \mathrm{M}$ of cladosporol A for $24 \mathrm{~h}$. TZD $(10 \mu \mathrm{M})$ was used as positive control of $\mathrm{p} 21^{\text {waf1/cip } 1}$ promoter transcriptional activity. Luciferase activities were normalized to the $\beta$ galatosidase ones used as control. Data shown are mean \pm SD of three independent experiments performed in duplicate. (E) Functional analysis of the transcriptional activity of $\mathrm{p} 21^{\text {waf1/cip } 1}$ promoter gene by deletion and site-directed mutagenesis. Left: structural features of the recombinant plasmids carrying the mutated forms of the p21 waf1/cip1 promoter used in this study. Right: results of the transiently transfections in HT-29 cells as fold induction of luciferase activity and obtained with the p21 $1^{\text {waf } 1 / \text { cip } 1}$ promoter-luciferase plasmids reported in the left panel. Cells were treated with $20 \mu \mathrm{M}$ of cladosporol A for $24 \mathrm{~h}$. The luciferase activities were normalized to the $\beta$-galatosidase ones used as control. Data shown are mean $\pm S D$ of three independent experiments performed in duplicate.

in which the third Sp1 binding site is mutated, caused only a slight induction of luciferase activity. Plasmid pWP101-mtSp1-4 with a mutated binding site 4 did not affect the luciferase activity increase of the intact $124 \mathrm{bp}$ long promoter, 
whereas plasmid pWP101-mtSp1-5/6 with mutated Sp1 binding sites $5 / 6$ caused a very low, if any, luciferase activity. These results indicate that the two more upstream Sp1 binding sites do not affect p21 waf1/cip1 transcriptional efficiency, while the Sp1 binding sites 3 and 5/6 appear to play a central role in mediating the formation of a transcriptional apparatus capable to promote gene expression.

Cladosporol A Treatment of HT-29 Cells Induces an Oxidative Stress-Response and Activates the MAPK Pathways

To further investigate the protein variations induced by cladosporol A in HT-29 cells, a proteomic analysis was performed on cells treated or not with $20 \mu \mathrm{M}$ cladosporol A for $8 \mathrm{~h}$. Total protein extracts were separated on PAGEs covering a 4-7 $\mathrm{pH}$ range and $10-150 \mathrm{kDa} \mathrm{Mr}$ ranges, followed by a Coomassie-based reagent staining. All gel images from treated and untreated cells were acquired and quantitatively evaluated (Supplementary data 2). About 30 spots showed at least a twofold difference in relative absorbance between samples; 21 spots were associated to protein sequence entries by different MS approaches (Supplementary data 3). Chaperones, structural proteins, transcription and translation factors, cell cycle regulators, redox response modulators and apoptotic proteins were identified among those whose expression changes after cladosporol A treatment.

To confirm that the protein changes observed after drug treatment were dependent upon an oxidative stress response, total protein extracts from proliferating HT-29 cells exposed to $20 \mu \mathrm{M}$ cladosporol A, for 4,6 , and $8 \mathrm{~h}$ were analyzed by Western blotting with antibodies recognizing the phosphorylated forms of ERK and JNK. Both proteins increased after treatment (Figure 7A,B). To demonstrate that both signaling pathways mediate the cladosporol A-induced redox response, we then treated HT-29 cells as above in the presence or absence of increasing concentrations of NAC ( $\mathrm{N}$-acetyl-cysteine), an inhibitor of redox species accumulation. Exposure to $20 \mu \mathrm{M}$ cladosporol A caused a simultaneous increase in $\mathrm{p} 21^{\text {waf1/cip1, }}$ pERK, and pJNK, while addition of increasing concentrations of NAC counteracted the drug-induced increase of the three proteins (Figure 7C).

To further prove the redox species enhancement by cladosporol A treatment, we assessed MDA production through a lipid peroxydation assay as well as the involvement of the NADPH oxydase, the main enzymatic machinery responsible of ROS generation. An increase in the production of reactive species was firstly observed, confirming that cladosporol A induces a redox response (Supplementary data 4A). Afterwards, we analyzed whether the cladosporol A-induced ROS generation was prevented by the NADPH oxidase specific inhibitor apocynin. The results shown in Supplementary data 4B demonstrate that preincubation with apocynin, before cladosporol A exposure, results in a reduced $\mathrm{p} 21^{\text {waf1/cip } 1}$ expression, suggesting that cladosporol A induces NADPH oxidase-dependent ROS generation.

Finally, to further demonstrate the functional link between ERK pathway and p21 waf1/cip1 expression, we treated HT-29 cells with two MEK inhibitors, PD98059 and UO126. The results indicated that $\mathrm{p} 21^{\text {waf1/cip1 }}$ was up-regulated only when the pathway is functional; when pERK was blocked, no p21 $1^{\text {waf1/cip1 }}$ increase was observed (Figure 7D).

These results provide the first evidence that ERK (and JNK also) might function as mediator of the cladosporol A-induced inhibition of HT-29 cell growth. Although additional experiments must be performed to clarify the interplay between the different signaling pathways activated by cladosporol A, our preliminary data suggest that the mitogen-activated protein kinase (MAPK) pathways are involved in the cladosporol A-induced regulation of HT-29 cells proliferation.

\section{DISCUSSION}

In this paper, we provide evidence that cladosporol A displays antiproliferative activity in human CRC derived cell lines, specifically in HT29 cells (Figures 1B and 2A-C). The inhibition of cell proliferation is reversible at lower doses (5 and $10 \mu \mathrm{M})$, as the cells can escape the cell cycle arrest; in contrast, cell proliferation is irreversibly reduced at higher doses $(20 \mu \mathrm{M})$ (Figure 2B), suggesting that cladosporol A could act as a cytostatic rather than a cytotoxic compound in human CRC derived cells (Figure 2B and Supplementary data 1). Similar results were obtained in other cell lines of the same origin; the effects were more pronounced in HT-29, likely due to their different genotypes that could impart a different response to the drug (for details see in Materials and Methods Section).

Inhibition of cell growth by cytostatic agents is generally accompanied by a cell cycle arrest at specific phases. Higher doses of cladosporol A were associated with a specific G1 phase arrest, while, surprisingly, lower doses were associated with cell accumulation at the G2/M phase (Figure 3 and Table 1). Other molecules can cause both a G1 and a $\mathrm{G} 2 / \mathrm{M}$ arrest at different concentrations. Quercetin, a flavonoid derived from grape, caper, red onion, and green tea, induces a G2/M arrest at lower $(14.8 \mu \mathrm{M})$ and a $\mathrm{G} 1$ arrest at higher concentrations $(52.1 \mu \mathrm{M})$ [42]. Silibinin, the major component of milk thistle extract isolated from 
A
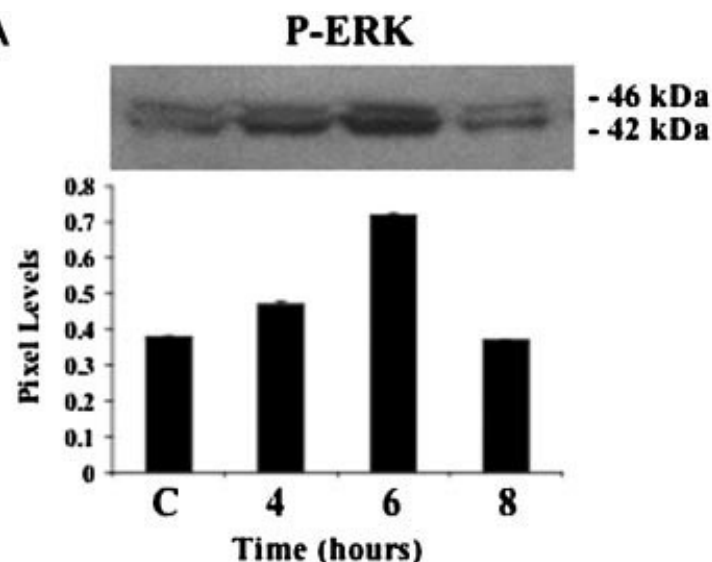

C

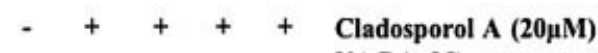

p21 wafi/Cip $\quad-21 \mathrm{kDa}$
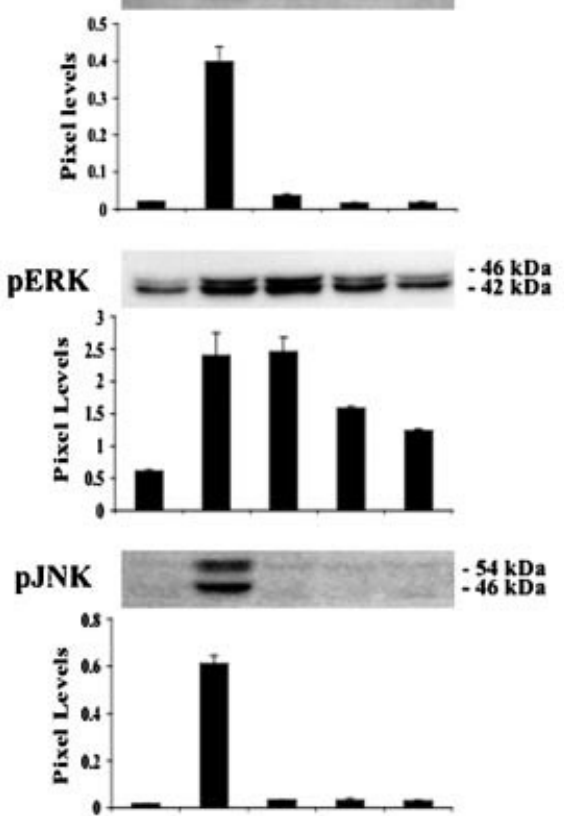

Figure 7. Cladosporol A treatment of HT-29 cells induces an oxidative stress-response and activates the MAPK pathways. Cells were treated or not with $20 \mu \mathrm{M}$ cladosporol A, for 4,6 , and $8 \mathrm{~h}$. Cell lysates were prepared in non-denaturing lysis buffer and then analyzed by Western blotting using antibodies specifically recognizing the phosphorylated forms of ERK (A) and JNK (B) or $\beta$-actin (control). The bar graphs represent the mean \pm SD of $p E R K$ or $\mathrm{pJNK} / \beta$-actin of three independent experiments. Western blotting assays reported here are representative of a single exemplificative experiment. (C) Cells were treated or not with $20 \mu \mathrm{M}$ cladosporol $\mathrm{A}$, for $4 \mathrm{~h}$ in absence and presence of increasing concentrations of NAC ( $N$-acetyl-cysteine). Cell lysates were prepared in non-denaturing lysis buffer and then analyzed by Western blotting using

Sylibum marianum, on the contrary, induces a G1 arrest at lower concentrations (50 and $75 \mu \mathrm{M})$, whereas provokes a $\mathrm{G} 2 / \mathrm{M}$ block at higher concentrations $(100 \mu \mathrm{M})$ [43].

The $\mathrm{G} 2 / \mathrm{M}$ phase arrest that mainly occurs in cells bearing DNA damages, allows these

\section{B P-JNK}

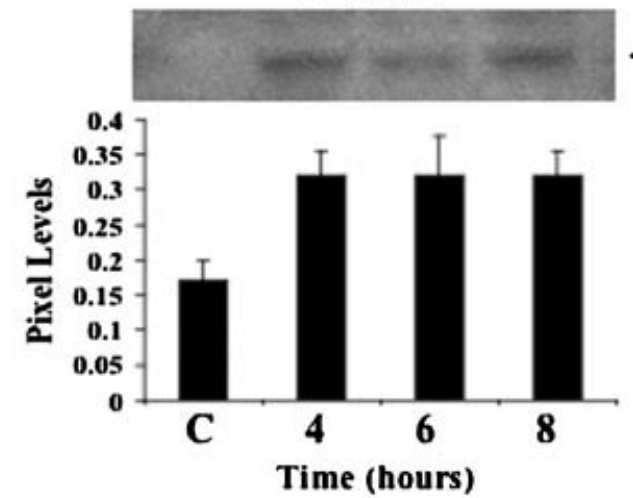

$-54 \mathrm{kDa}$

D
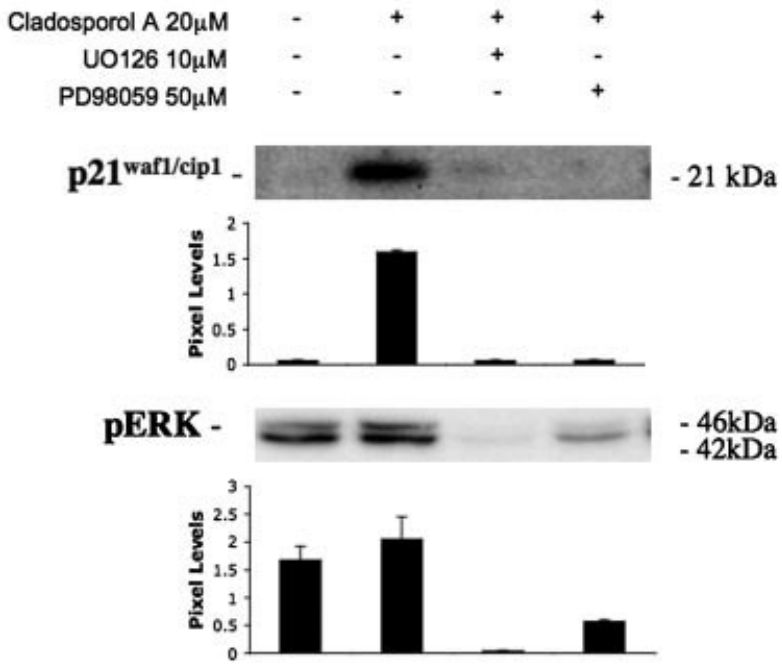

antibodies specifically recognizing the phosphorylated forms of p21 $1_{\text {waf1/cip1, }}$ ERK, and pJNK. The bar graphs represent the mean \pm SD of $\mathrm{p} 21^{\text {waf1/cip } 1}$ or $\mathrm{pERK}$ or $\mathrm{pJNK} / \beta$-actin of three independent experiments. Western blotting assays reported here are representative of a single exemplificative experiment. (D) Cells were treated or not with $20 \mu \mathrm{M}$ cladosporol $\mathrm{A}$, for $4 \mathrm{~h}$ in absence and presence of U0126 $10 \mu \mathrm{M}$ and PD98059 $50 \mu \mathrm{M}$. Cell lysates were prepared in non-denaturing lysis buffer and then analyzed by Western blotting using antibodies specifically recognizing 221 wat cip 1 sterk cip and pERK. The bar graphs represent the mean \pm SD of p21 or pERK / $\beta$-actin of three independent experiments. Western blotting assays reported here are representative of a single exemplificative experiment.

injuries to be repaired before cells proceed into mitosis, thereby preventing the stabilization of the mutations. Accumulation of cells at the G2/M phase observed with lower dosage suggests that cladosporol A somehow inhibits DNA replication. 
On the contrary, at higher dosage, cladosporol A hits different molecular targets as documented by changes in the expression of $\mathrm{p} 21^{\text {waf1/cip } 1}$ and cyclin D1 (Figure 3). p21 waf1/cip1 is considered as the universal inhibitor of cell cycle progression: it is upregulated in G1 and in G2/M phase and this bimodal periodicity of expression suggests a role in the control of both phases of the cell cycle [44]. The robust increase in $\mathrm{p} 21^{\text {waf1/cip1 }}$ expression, which we found in cells blocked at G1 phase, likely indicates that, in our case, p21 waf1/cip1 exerts its effect in this phase (Figure $3 \mathrm{~B}$ ).

In proliferating HT-29 cells, indeed, we also found a remarkable reduction in cyclin D1, cyclin E, CDK2, and CDK4 expression after cladosporol A treatment (Figures 4 and 5), proteins largely involved in the G1/S restriction point control. All together, a down-expression of cyclin D1, cyclin E, CDK2, and CDK4 and a simultaneous over-expression of $\mathrm{p} 21^{\text {waf } 1 / \mathrm{cip} 1}$ appears to influence the $\mathrm{p} 21^{\text {waf1/cip } 1}$ ability to bind the cyclinE/CDK2 complex and, consequently, to generate a reduced kinase activity. The data reported in Figure $5 \mathrm{~L}$ demonstrate that the cyclinE/CDK2 complex, that peaks at G1/S transition and usually phosphorylates several proteins, after cladosporol A treatment, is not longer able to phosphorylate the histone $\mathrm{H} 1$, confirming the inhibition of the G1/S transition and the cell cycle arrest in HT29 cells.

In proliferating HT-29 cells, the increased $\mathrm{p} 21^{\text {waf1/cip } 1}$ expression is accompanied by reduced levels of cyclin D1 and PCNA (Figures 3-5), confirming the role they play in regulating the $\mathrm{G} 1 / \mathrm{S}$ progression. Indeed, p21 waf1/cip1 binds the cyclin D1-CDK4/CDK6 complexes and inhibits their kinase activity toward RB protein, stimulating a proteasomal degradation of the complexes and promoting a proliferation arrest [45]. Since we found a reduced expression of RB protein expression after cladosporol A treatment (Figure 5I), it is conceivable that this event results in an attenuated RB-associated cyclin D1/CDK4 kinase activity. p2 $1^{\text {waf1/cip } 1}$ is also a strong inhibitor of the DNA polymerase auxiliary protein, PCNA, through its carboxy-terminal domain [46]. The diminished expression of PCNA, shown in Figure 5E, is the demonstration of the cladosporol A-induced action of p21 $1^{\text {waf1/cip } 1}$.

Cyclin B1 and Cdc2-p34, known markers of the $\mathrm{G} 2 / \mathrm{M}$ arrest, are also reduced, suggesting that cladosporol $\mathrm{A}$ at higher doses probably overcomes the effects induced by lower doses (Figure 5B,D). However, we cannot exclude that, even at higher doses, HT-29 cells are partially arrested at the $\mathrm{G} 2 / \mathrm{M}$ phase as documented by the reduction of the Cdc2-p34 protein (Figure 5D). More experiments are required to study the detailed mechanisms by which cladosporol A inhibits HT-
29 cell proliferation through the $\mathrm{G} 2 / \mathrm{M}$ phase arrest.

$\mathrm{p} 21^{\text {waf } 1 / \mathrm{cip} 1}$ expression is finely regulated by different mechanisms at the post-transcriptional level; however, the most efficient way to modulate its expression occurs at the transcriptional level through both p53-dependent and p53-independent mechanisms that involve a variety of factors [38]. p53, in turn, trans-activates several genes involved in growth control and the presence of two p53responsive elements in the promoter region of the mouse, rat and human p21 $1^{\text {waf1/cip1 }}$ genes suggests a role for this protein in transcription activation after DNA damage [38]. Other stimuli (RAS, c-Rel, Neu Diff. Factor, Zta, ribonucleotide inhibitors) can induce $\mathrm{p} 21^{\text {waf1/cip1 }}$ gene expression through up-regulation and/or stabilization of the p53 protein [38]. Also, induction of p53independent $\mathrm{p} 21^{\text {waf1/cip1 }}$ gene transcription requires the activation of transcription factors by different stimuli and binding to their cognate sequences in the promoter region. Phorbol ester (PMA) and okadaic acid induce p $21^{\text {waf1/cip1 }}$ gene transcription by stimulating $\mathrm{Sp} 1$ binding to the corresponding response elements in human leukemic cell U937 [47]. Also butyrate, transforming growth factor$\beta$ (TGF- $\beta$ ), lovastatin, trichostatin $A$, and NGF induce $\mathrm{p} 21^{\mathrm{waf} 1 / \mathrm{cip} 1}$ gene transcription. Indeed, several Sp1 binding sites are clustered within the $120 \mathrm{bp}$ proximal to the transcription start site in the $\mathrm{p} 21^{\text {waf1/cip } 1}$ human gene promoter; in all cases, the role of the $\mathrm{Sp} 1$ site 3 resulted to be crucial [36,48-51]. The experiments presented here (Figure 6) clearly show that a major role in $\mathrm{p} 21^{\text {waf1/cip } 1}$ induction by cladosporol $\mathrm{A}$ is played by Sp1 and not by p53. Deletion of the p53 binding sites did not affect the response, whereas deletion or site-directed mutants of the Sp1binding sites caused a dramatic reduction of $\mathrm{p} 21^{\text {waf1/cip } 1}$ reporter gene expression (Figure 6E). Note that HT-29 cells bear a mutated form of p53 and, in fact, we observed no significant variations in p53 expression after cladosporol A treatment $(20 \mu \mathrm{M}$ for 4,6 , and $8 \mathrm{~h}$ ) (Supplementary data 5). In addition, we tested the effects of cladosporol A both in p53 $+/+$ and p53-/- HCT116 cells. Despite a difference in basal p2 $1^{\text {waf1/cip1 }}$ protein levels, the relative increase in p21 waf1/cip1 expression, which we detected in both cells, was similar, confirming that the presence of a functional p53 is not required (Supplementary data 6$)$. The increase in $\mathrm{p} 21^{\text {waf1/cip } 1}$ expression is associated to the G1 phase arrest also in cladosporol A-treated p53 +/+ and p53-/- HCT116 cells as reported in Supplementary Data 7. Both cell types are blocked in G1 phase, even if only for $12 \mathrm{~h}$, and then they start again to progress in the cell cycle, demonstrating that the G1 arrest does not depend on p53. The shorter cell cycle arrest observed in both p53 +/+ and p53-/- HCT116 cells could be 
due to the different cellular context in which cladosporol A exerts its action.

Although we definitively demonstrated that activation of $\mathrm{p} 21^{\text {waf1/cip } 1}$ gene transcription by cladosporol A in HT-29 cells involves a p53independent pathway, we cannot exclude that other mechanisms and protein factors may be involved in the G1 phase arrest and inhibition of cell proliferation observed, in addition to the gene expression variations reported. To this aim, we analyzed changes in the HT-29 cells proteome, following treatment with cladosporol A and found that the steady state of several proteins was modified (Supplementary Data 3). Interestingly, among these, some play a central role in controlling the oxidative stress response of the cell. Specifically, the MAPK cascades, such as ERK, JNK, and p38 pathways, are activated in response to oxidant species accumulation after administration of chemiopreventive agents. We provide evidence that higher doses of cladosporol A stimulate an oxidative stress via different mechanisms and induce an adaptative response through activation of the ERK and JNK pathways (Figure 7), resulting in a p21 waf1/cip1 increase, cyclin D1 decrease, G1 phase arrest and reduced cell proliferation. Recent reports demonstrated that cyclin D1 expression and p53-independent $\mathrm{p} 21^{\text {waf1/cip } 1}$ induction are modulated through the MAPK pathways in various cell lines [52,53]. Although the data obtained by proteome analysis need to be expanded, they indicate that other factors could, directly or indirectly, be targeted by the treatment and that intricate mechanisms could integrate the different actions of cladosporol A in controlling cancer cell proliferation.

In summary, in this work we demonstrated that cladosporol $\mathrm{A}$ is responsible for a diminished CRC cells proliferation, especially in HT-29 cells, caused by a G1 phase arrest and determined by the simultaneous increase of $\mathrm{p} 21^{\text {waf1/cip } 1}$ and decrease of several cell cycle regulators. The enhanced p21 waf1/cip1 protein levels are generated by an intense Sp1dependent, p53-independent p21 $1^{\text {waf1/cip } 1}$ induction of gene transcription. The results of this work demonstrate for the first time that ERK (and JNK also) might function as mediator of the cladosporol A-induced inhibition of HT-29 cell growth, suggesting the existence of a regulatory circuit that integrates cell cycle regulation and the signaling pathways both converging towards inhibition of cell proliferation.

\section{ACKNOWLEDGMENTS}

Authors thank Dr. Y. Sowa for the gift of the recombinant plasmids of $\mathrm{p} 21^{\text {waf1/cip } 1}$ promoter region. This work was partially supported by grants from MIUR (PRIN2006 to V. C.). This work was partially supported by grants from MIUR (FIRB-
RBNE08YFN3, PRIN 2008CCPKRP_002/003) and Regione Campania (Rete di Spettrometria di MassaRESMAC) to A.S.

\section{REFERENCES}

1. Milner JA. Molecular target for bioactive food components. J Nutr 2004;134:2492S-2498S.

2. Chen C, King A. Dietary cancer-chemopreventive compounds: From signalling and gene expression to pharmacologica. Trends Mol Med 2005;26:318-328.

3. Manson M, Farmer P, Gensher A, Steward W. Innovative agents in cancer prevention Recent Results Cancer Res 2005; 166:257-275.

4. Nasini G, Arnone A, Assante G, Bava A, Moricca S, Ragazzi A. Secondary metabolites of Cladosporium tenuissimum, a hyperparasite of rust fungi. Phytochemistry 2004;65:2104-2111.

5. Moricca S, Ragazzi A, Mitchelson KR. Molecular and conventional detection and identification of Cladosporium tenuissimum on two-needle pine rust aeciospores. Can J Bot 1999;77:339-347.

6. Sakagami Y, Sano A, Hara O, Mikawa T, Marumo S. Cladosporol, $\beta-1,3-$ glucan biosynthesis inhibitor, isolated by the fungus Cladosporium cladosporioides. Tetrahedron Lett 1995;36:1469-1472.

7. Fukushima $Y$, Sakagami $Y$, Marumo S. $\beta$-glucan biosynthesis inhibitors isolated from fungi as hyphal malformation inducers. Bioorganic Med Chem Lett 1993;3:12191222.

8. Sakagami Y, Sano A, Marumo S, Yoshikawa N, Nakagawa J. Cladosporol, a plant growth regulator produced by fungus Cladosporium cladosporioides. Tennen Yuki Kagobutsu Toronkai Koen Yoshishu 1992;34:134-141.

9. Moricca S, Ragazzi A, Mitchelson KR, Assante G. Antagonism of the two-needle pine stem rust fungi Cronartium flaccidum and Peridermium pini by Cladosporium tenuissimum in vitro and in planta. Phytopathology 2001;91:457468.

10. Moricca S, Ragazzi A, Assante G. Biocontrol of rust fungi by Cladosporium tenuissimum. In: Hao Pei M, McCracken AR, editors. Rust diseases of willow and poplar. International, Wallingford, UK: CABI Publishing; 2005. pp. 213229.

11. Assante G, Bava A, Nasini G. Enhancement of a pentacyclic tyrosine kinase inhibitor production in Cladosporium cf. cladosporioides by Cladosporol. Applied Microbiol Biotechnol 2006:69:718-721.

12. Jemal A, Siegel R, Ward E, Hao $Y$, Thun MJ. Cancer statistics. CA Cancer J Clin 2009;4:225-249.

13. Samowits WS, Curtin K, Ma KN, et al. Prognostic significance of p53 mutations in colon cancer at the population level. Int. J Cancer 2002;99:597-602.

14. Sebolt-Leopold JS, Dudley DT, Herrera R, et al. Blockade of the MAP kinase pathway suppresses growth of colon tumors in vivo. Nat Med 1999;5:810-816.

15. Torrance CJ, Jackson PE, Montgomery E, et al. Combinatorial chemoprevention of intestinal neoplasia. Nat Med 2000;6:1024-1028.

16. Buolamwini JK. Cell cycle molecular target in novel anticancer drug discovery. Curr Pharm Des 2000;6:379_ 392.

17. Sausville EA, Johnson J, Alley M, Zaharevitz D, Senderowicz AM. Inhibition of CDKs as a therapeutic modality. Ann NY Acad Sci 2000;910:207-221.

18. Tannoch VJ, Hinds PW, Tsai LH. Cell cycle control. Advan in Experim Med and Biol 2000;465:127-140.

19. Morgan D. Cyclin dependent kinases: Engines, clocks and microprocessors. Annu Rev Cell Dev Biol 1997;13:261-291.

20. Malumbres M, Barbacid M. To cycle or not to cycle: A critical decision in cancer. Nat Rev Cancer 2001;1:222231. 
21. Sherr CJ, Roberts JM. CDK inhibitors: Positive and negative regulators of G1-phase progression. Genes Dev 1999; 13:1501-1512.

22. Pavletich NP. Mechanism of cyclin-dependent kinase regulation structures of cdks, their cyclin activators, and CIP and INK4 inhibitors. J Mol Biol 1999;287:821-828.

23. Sandal T. Molecular aspects of the mammalian cell cycle and cancer. Oncologist 2002;7:73-81.

24. Gu Y, Turck CW, Morgan DO. Inhibition of CDK2 activity in vivo by an associated $20 \mathrm{~K}$ regulatory subunit. Nature 1993;366:707-710.

25. Deiry WS, Tokino T, Velculescu VE. Waf1, a potential mediator of p53 tumor suppression. Cell 1993;75:817825

26. Jiang $H$, Lin J, Su ZZ, Collart FR, Huberman E, Fisher PB. Induction of differentiation in human promyelocitic HL-60 leukemia cells activates p21, WAF/CIP1, expression in the absence of p53. Oncogene 1994;9:3397-3406.

27. Steinman RA, Hoffman B, Iro A, Guillouf C, Lieberman DA, el-Houseini ME. Induction of p21 (WAF/CIP1) during differentiation. Oncogene 1994;9:3389-3396.

28. Gonzales CA. Nutrition and cancer: The current epidemiological evidence. Br J Nutr 2006:96:S42-S45.

29. Messina $M$, Barnes $S$. The role of soy products in reducing risk of cancer. J Natl Cancer Inst 1991;83:541-546.

30. Agarwal C, Singh RP, Dhanalakshmi S, et al. Silibilin upregulates the expression of cylin-dependent kinase inhibitors and causes cell cycle arrest and apoptosis in human colon carcinoma HT-29cells. Oncogene 2003;22: 8271-8282.

31. $Y u Z$, Li W, Liu F. Inhibition of proliferation and induction of apoptosis by genistein in colon cancer HT-29cells. Cancer Lett 2004;215:159-166.

32. Shen $G, X u C$, Chen C, Hebbar V, Kong AT. p53independent $\mathrm{G} 1$ cell cycle arrest of human colon carcinoma cells HT-29 by sulforaphane is associated with induction of p21 and inhibition of expression of expression of cyclin D1. Cancer Chemother Pharmacol 2006;57:317327

33. Chen J, Qiu X, Wang R, et al. Inhibition of human gastric carcinoma cell growth in vitro and in vivo by cladosporol isolated from the paclitaxel-producing strain Alternaria alternata var. monosporus. Biol Pharm Bull 2009;32: 2072-2074.

34. Wang W, Heideman L, Ching CS, Pelling JC, Koehler KJ, Birt DF. Cell-cycle arrest at G2/M and growth inhibition by apigenin in human colon carcinoma cell lines. Mol Carcinog 2000:28:102-110.

35. Matsui TA, Sowa $Y$, Murata $H$, et al. The plant alkaloid cryptolepine induces $\mathrm{p} 21^{\text {waf1/Cip } 1}$ and cell cycle arrest in a human osteosarcoma cell line. Int J Oncol 2007;31:915922

36. Nakano K, Mizuno T, Sowa Y, et al. Butyrate activates the WAF1/CIP1 gene promoter through Sp1 sites in a p53negative human colon cancer cell line. J Biol Chem 1997; 272:22199-22206.

37. Vascotto C, Cesaratto L, D'Ambrosio C, et al. Proteomic analysis of liver tissues subjected to early ischemia/reperfusion injury during human orthotopic liver transplantation. Proteomics 2006:6:3455-3465.

38. Gartel AL, Tyner AL. Transcriptional regulation of the p21 $1^{\text {waf1/cip } 1}$ gene. Exp Cell Res 1999;246:280-289.
39. Han S, Sidell N, Fisher PB, Roman J. Up-regulation of p21 gene expression by peroxisome proliferator-activated receptor $\gamma$ in human lung carcinoma cells. Clin Cancer Res 2004; 10:1911-1919.

40. Hong JK, Samudio I, Liu S, Abdelrahim M, Safe S. Peroxisome proliferator-activated receptor $\gamma$-dependent activation of p21 in Panc-28 pancreatic cancer cells involves Sp1 and Sp4 proteins. Endocrinology 2004;145:5774-5785.

41. Bonofiglio D, Qi H, Gabriele S, et al. Peroxisome proliferator-activated receptor $\gamma$ inhibits follicular and anaplastic thyroid carcinoma cells growth by upregulating p21 waf1/ cip1 gene in a Sp1-dependent manner. Endocrine Relat Cancer 2008; 15:545-557.

42. Ong CS, Tran E, Nguyen TT, et al. Quercetin-induced growth inhibition and cell death in nasopharyngeal carcinoma cells are associated with increase in Bad and hypophosphorylated retinoblastoma expressions. Oncol Rep 2004;11:727-733.

43. Agarwal C, Singh RP, Dhanalakshmi S, et al. Silibinin upregulates the expression of cyclin-dependent kinase inhibitors and causes cell cycle arrest and apoptosis in human colon carcinoma HT-29cells. Oncogene 2003;22:82718282.

44. Grana X, Reddy P. Cell cycle control in mammalian cells: Role of cyclins, cyclin dependent kinases (CDKs), growth suppressor genes and cyclin-dependent kinase inhibitors (CKIs). Oncogene 1995;11:211-219.

45. Paggi MG, Baldi A, Sonetto F, Giordano A. Retinoblastoma protein family in cell cycle and cancer: A review. J Cell Biochem 1996;62:418-430.

46. Cayrol C, Knibiehler M, Ducommun B. p21 binding to PCNA causes $\mathrm{G} 1$ and $\mathrm{G} 2$ cell cycle arrest in p53-deficient cells. Oncogene 1998;16:311-320.

47. Biggs JR, Kudlow JE, Kraft AS. The role of the transcription factor Sp1 in regulating the expression of the WAF1/ CIP1 gene in U937 leukemic cells. J Biol Chem 1996; 271:901-906.

48. Datto $M B, Y u Y$, Wang XF. Functional analysis of the transforming growth factor beta responsive elements in the WAF1/Cip1/p21 promoter. J Biol Chem 1995;270: 28623-28628

49. Lee SJ, Ha MJ, Lee J, et al. Inhibition of the 3-hydroxy-3methylglutaryl-coenzime $A$ reductase pathway induces p53-independent transcriptional regulation of p21(WAF1/ CIP1) in human prostate carcinoma cells. J Biol Chem 1998;273:10618-10623.

50. Sowa Y, Orita T, Minamikawa S, et al. Histone deacetylase inhibitor activates the WAF1/Cip1 gene promoter through the Sp1 sites. Biochem Biophys Res Commun 1997; 241:142-150.

51. Billon N, Carlisi D, Datto MB, van Gruyten LA, Wang XF, Rudkin B. Cooperation of Sp1 and p300 in the induction of the CDK inhibitor p21/WAF1/CIP1 during NGFmediated neuronal differentiation. Oncogene 1999;6: 2872-2882.

52. Rooversand K, Assoian RK. Integrating the MAP kinase signal into the $\mathrm{G} 1$ phase cell cycle machinery. Bioessays 2000;22:818-826.

53. Oh SY, Park KS, Kim JA, Choi KY. Differential modulation of zinc-stimulated p21(Cip/WAF1) and cyclin D1 induction by inhibition of PI3 kinase in HT-29 colorectal cancer cells. Exp Mol Med 2002;34:27-31. 